Article

\title{
Volumetric Properties and Surface Tension of Few-Layer Graphene Nanofluids Based on a Commercial Heat Transfer Fluid
}

\author{
Samah Hamze ${ }^{1}{ }^{\oplus}$, David Cabaleiro ${ }^{1,2}{ }^{\oplus}$, Dominique Bégin ${ }^{3}$, Alexandre Desforges ${ }^{4}$, \\ Thierry Maré ${ }^{1}$, Brigitte Vigolo ${ }^{4}\left(\mathbb{D}\right.$, Luis Lugo ${ }^{2}(\mathbb{D})$ and Patrice Estellé ${ }^{1, *}$ \\ 1 Laboratoire de Génie Civil et Génie Mécanique, Université de Rennes, F-35000 Rennes, France; \\ samah.hamze@univ-rennes1.fr (S.H.); dacabaleiro@uvigo.es (D.C.); thierry.mare@univ-rennes1.fr (T.M.) \\ 2 Departamento de Física Aplicada, Facultade de Ciencias, Universidade de Vigo, E-36310 Vigo, Spain; \\ luis.lugo@uvigo.es \\ 3 Institut de Chimie et Procédés pour l'Energie, l'Environnement et la Santé (ICPEES) CNRS-University of \\ Strasbourg, 25, rue Becquerel, F-67087 Strasbourg Cedex, France; dominique.begin@unistra.fr \\ 4 Institut Jean Lamour UMR7198, Université de Lorraine, CNRS, F-54000 Nancy, France; \\ alexandre.desforges@univ-lorraine.fr (A.D.); brigitte.vigolo@univ-lorraine.fr (B.V.) \\ * Correspondence: patrice.estelle@univ-rennes1.fr; Tel.: +33-0223-234-200
}

Received: 9 June 2020; Accepted: 2 July 2020; Published: 4 July 2020

check for updates

\begin{abstract}
Volumetric properties such as density and isobaric thermal expansivity, and surface tension are of paramount importance for nanofluids to evaluate their ability to be used as efficient heat transfer fluids. In this work, the nanofluids are prepared by dispersing few-layer graphene in a commercial heat transfer fluid Tyfocor ${ }^{\circledR}$ LS (40:60 wt.\% propylene-glycol/water) with the aid of three different nonionic surfactants: Triton X-100, Pluronic ${ }^{\circledR}$ P-123 and Gum Arabic. The density, isobaric thermal expansivity and surface tension of each of the base fluids and nanofluids are evaluated between 283.15 and $323.15 \mathrm{~K}$. The influence of the mass content in few-layer graphene from 0.05 to $0.5 \%$ on these nanofluid properties was studied. The density behavior of the different proposed nanofluids is slightly affected by the presence of graphene, and its evolution is well predicted by the weight-average equation depending on the density of each component of the nanofluids. For all the analyzed samples, the isobaric thermal expansivity increases with temperature which can be explained by a weaker degree of cohesion within the fluids. The surface tension evolution of the graphene-based nanofluids is found to be sensitive to the used surfactant, its content and the few-layer graphene concentration.
\end{abstract}

Keywords: few-layer graphene; propylene-glycol/water; nanofluids; density; surface tension; isobaric thermal expansivity

\section{Introduction}

Nanofluids are suspensions of nanoparticles (1-100 nm in size) dispersed in base fluids commonly used in heat transfer processes [1]. These engineering materials are potentially attractive for many applications in the energy field including cooling engines and electronic circuits or increasing and recovering solar thermal energy [2]. In the last century, the enhancement of thermal performance has become a key issue in the energy field considering the rapid growth in energy consumption worldwide [3-5]. Interestingly, many studies have reported enhancement of thermal conductivity and heat transfer performance of nanofluids. The found key parameters are both the nature of nanoparticles and effect of the used base fluids, as given in some articles on this topic [2,6-14]. Carbon nanomaterials are of major interest in this field due to their excellent intrinsic thermal properties, which are superior to 
those of metallic or metal oxide nanoparticles; carbon nanomaterials such as carbon nanotubes (CNTs) or graphene are consequently expected to be better thermal enhancers in nanofluid design $[5,15]$. In particular, graphene exhibits the best characteristics regarding its thermal conductivity spectrum amongst the carbon nanomaterials $[5,15,16]$. Graphene is a sheet of an atomic thickness only composed of carbon atoms which are hybridized $\mathrm{sp}^{2}$ and arranged in a honeycomb network. Thermophysical behavior of graphene-based nanofluids has been the topic of several investigations [17-19]. However, so far, analysis and evolution of the surface tension (ST) of graphene-based nanofluids, which is another important aspect to take into account in nanofluid behavior, has been overlooked [20].

When analyzing the performance of thermal systems, evolution of ST has a significant impact on the surface properties such as wettability [21,22]. Hence, together with the vaporization latent heat of the nanofluid and the difference between the density of the liquid and the vapor phase, nanofluid ST allows the description of condensation and boiling phenomena $[23,24]$. The ST study is especially a relevant parameter to study for graphene nanofluid since, as it is widely known, graphene is highly hydrophobic. Pristine graphene nanosheets have consequently high tendency to agglomerate in all common aqueous solvents and particularly those (often water or water/glycol-based compound mixtures) used as thermal medium $[5,25,26]$. Decrease in hydrophobicity or in other words improving affinity of graphene with water can be obtained by non-covalent or covalent functionalization of graphene surface. Such chemical treatments can be involved in ST evolution of graphene-based nanofluids. As shown in Table 1, studies about ST of graphene-based nanofluids are limited.

Table 1. Summary of previous surface tension studies on graphene nanofluids.

\begin{tabular}{|c|c|c|c|c|c|c|}
\hline \multirow{2}{*}{ Reference } & \multicolumn{2}{|c|}{ Nanoparticle } & \multirow{2}{*}{ Base Fluid } & \multirow{2}{*}{$\begin{array}{l}\text { Surfactant (np:sft } \\
\text { Ratio) }\end{array}$} & \multirow{2}{*}{$\begin{array}{l}\text { Surface Tension } \\
\text { Technique }\end{array}$} & \multirow{2}{*}{$\begin{array}{l}\text { Main Result with } \\
\text { NP Loading }\end{array}$} \\
\hline & Type & Concentration & & & & \\
\hline Ahammed et al. [27] & Graphene & 0-0.15 vol. $\%$ & Water & $\begin{array}{c}\text { SDBS } \\
(5 \text { vol. } \%)\end{array}$ & $\begin{array}{l}\text { Bubble pressure } \\
\text { method }\end{array}$ & $\mathrm{ST} \downarrow$ \\
\hline Cabaleiro et al. [5] & $\begin{array}{l}\text { Graphene oxide } \\
\text { and reduced } \\
\text { graphene oxide }\end{array}$ & $0-0.1$ vol. $\%$ & Water & No surfactant & $\begin{array}{l}\text { Pendant drop } \\
\text { method }\end{array}$ & $\mathrm{ST} \downarrow$ \\
\hline Ilyas et al. [28] & $\begin{array}{l}\text { Graphene } \\
\text { nanoplatelets }\end{array}$ & $0-0.25$ wt. $\%$ & $\begin{array}{c}\text { Saline aqueous } \\
\text { media }(\mathrm{NaCl})\end{array}$ & $\begin{array}{l}\text { SDS } \\
(1: 1.5)\end{array}$ & $\begin{array}{l}\text { Pendant drop } \\
\text { method }\end{array}$ & $\mathrm{ST} \downarrow$ \\
\hline Kamatchi et al. [29] & $\begin{array}{c}\text { Reduced } \\
\text { graphene oxide }\end{array}$ & $0-0.3 \mathrm{~g} / \mathrm{l}$ & Water & No surfactant & $\begin{array}{l}\text { Bubble pressure } \\
\text { method }\end{array}$ & $\mathrm{ST} \uparrow$ \\
\hline Liu et al. [30] & Graphene oxide & 0-0.12 wt.\% & Water & No surfactant & $\begin{array}{l}\text { Oscillation droplet } \\
\text { method }\end{array}$ & $\mathrm{ST} \uparrow$ \\
\hline Zheng et al. [31] & Graphene oxide & $0-1$ wt. $\%$ & Water & Not mentioned & Ring method & $\mathrm{ST} \uparrow$ \\
\hline
\end{tabular}

In 2014, Zheng studied the ST of water/graphene oxide (GO)-based nanofluids [31] and reported that ST increases with the rising of nanoparticle content. A maximum enhancement of about $3 \%$ (with respect to that of water) was found for the highest GO weight content used $0.1 \mathrm{wt} . \%$. The results have also shown that ST decreased when the nanoparticle size was reduced and when the temperature raised from 293.15 to $333.15 \mathrm{~K}$. Later, Kamatchi et al. investigated the ST of reduced graphene oxide (rGO) dispersed in water with nanoparticle concentration from 0.01 to $0.3 \mathrm{~g} / \mathrm{L}$ [29]. They also showed a decrease in ST when temperature increased from 308.15 to $348.15 \mathrm{~K}$. Graphene-water nanofluids were also recently investigated by Ahammed et al. [27]. The concentration of nanoparticles was varied from 0.05 to $0.15 \mathrm{vol} . \%$ and the tested temperature range was $283.15-363.15 \mathrm{~K}$. The nanofluids were prepared by dispersing a commercial graphene (with 1-5 nm of thickness) in water by using $5 \%$ of Sodium DodecylBenzene Sulfonate (SDBS) as surfactant. ST of these graphene-based nanofluids decreased with temperature $(3.3 \%$ for each $10 \mathrm{~K})$ and also with nanoparticle content. This behavior was related to the reduction of the attractive interactions between the fluid molecules and the nanoparticles by enhancing of nanoparticle absorption at liquid-gas interface since graphene is hydrophobic. Cabaleiro et al. [5] focused on the effect of graphene type (GO or rGO) and nanoparticle loading on ST of the prepared nanofluids with GO and two different reduction rates of rGO at different nanoparticle concentrations between 0.0005 and 0.1 vol.\%. The measurements, performed at room temperature, showed that ST decreased with graphene loading. The maximum reduction in ST (about $3 \%$ ) was obtained for the 
highest graphene volume fraction used. No significant effect of the chemical reduction of GO was observed on ST behavior. The surface tension of graphene oxide nanofluids was measured at low temperature by the oscillation droplet method in an acoustic levitator by Liu et al. [30]. The ST of these nanofluids was reported to increase with mass concentration (in the range from 0.02 to $0.12 \%$ ) and decrease with increasing temperature, with a strong effect of the subcooled temperature. Recently, Ilyas et al. [28] investigated temperature (298.15-338.15 K) and nanoparticle concentration (0-0.25 wt.\%) effects on the surface tension of graphene nanoplatelets-based saline $(\mathrm{NaCl})$ aqueous nanofluids using the pendant drop method. Samples were stabilized using anionic sodium dodecyl sulfate (SDS) at a nanoparticle:surfactant ratio of 1:1.5. Obtained results showed that the addition of nanoplatelets reduced the surface tension of the saline base fluid by $21 \%$ (modifications in ST were similar for the four analyzed graphene concentrations).

Some previous investigations on the density or volumetric behavior of graphene nanofluids are gathered in Table 2.

Table 2. Some volumetric behavior/density studies on graphene nanofluids.

\begin{tabular}{|c|c|c|c|c|c|c|}
\hline \multirow{2}{*}{ Reference } & \multicolumn{2}{|l|}{ Nanoparticle } & \multirow{2}{*}{ Base Fluid } & \multirow{2}{*}{ Surfactant } & \multirow{2}{*}{$\begin{array}{l}\text { Measuring } \\
\text { Technique }\end{array}$} & \multirow{2}{*}{$\begin{array}{l}\text { Main Result with } \\
\text { NP Loading }\end{array}$} \\
\hline & Type & Concentration & & & & \\
\hline Alawi et al. [32] & $\begin{array}{l}\text { Pentaethylene } \\
\text { glycol-(thermally)-treated } \\
\text { graphene nanoplatelets }\end{array}$ & 0-0.1 wt.\% & Water & No surfactant & $\begin{array}{l}\text { Vibrating } \\
\text { U-tube }\end{array}$ & $\rho \uparrow$ \\
\hline Amiri et al. [33] & $\begin{array}{l}\text { Amine-treated } \\
\text { graphene quantum dots }\end{array}$ & 0-0.02 wt.\% & Water & No surfactant & $\begin{array}{l}\text { Vibrating } \\
\text { U-tube }\end{array}$ & $\rho \rightarrow$ \\
\hline Azizi et al. [34] & $\begin{array}{l}\text { Functionalized } \\
\text { few-layer graphene }\end{array}$ & $\begin{array}{l}0.025,0.05 \\
0.1 \text { wt. } \%\end{array}$ & $\begin{array}{l}\text { Water, ethylene } \\
\text { glycol }\end{array}$ & PVA & $\begin{array}{l}\text { Vibrating } \\
\text { U-tube }\end{array}$ & $\rho \uparrow$ \\
\hline Cabaleiro et al. [16] & $\begin{array}{l}\text { Functionalized } \\
\text { graphene nanoplatelets }\end{array}$ & $\begin{array}{l}0.1,0.25,0.5 \\
\text { wt. } \%\end{array}$ & $\begin{array}{l}\text { Ethylene glycol: } \\
\text { water (10:90) }\end{array}$ & No surfactant & $\begin{array}{l}\text { Vibrating } \\
\text { U-tube }\end{array}$ & $\rho \uparrow, \alpha_{\mathrm{p}} \downarrow$ \\
\hline Ijam et al. [35] & $\begin{array}{l}\text { Graphene oxide } \\
\text { nanosheets }\end{array}$ & 0-0.1 wt.\% & $\begin{array}{l}\text { Ethylene glycol: } \\
\text { water (40:60) }\end{array}$ & No surfactant & $\begin{array}{l}\text { Vibrating } \\
\text { U-tube }\end{array}$ & $\rho \downarrow$ \\
\hline Karami et al. [36] & $\begin{array}{l}\text { Carboxyl-functionalized } \\
\text { graphene nanoplatelets }\end{array}$ & $0.1,0.2$ wt. $\%$ & Water & No surfactant & $\begin{array}{l}\text { Vibrating } \\
\text { U-tube }\end{array}$ & $\rho \rightarrow \uparrow$ \\
\hline Sani et al. [37] & $\begin{array}{l}\text { Functionalized } \\
\text { graphene nanoplatelets }\end{array}$ & $\begin{array}{l}0.005,0.05 \\
\text { wt. } \%\end{array}$ & $\begin{array}{l}\text { Havoline }{ }^{\circledR} \text { XLC } \\
\text { Premixed 50/50, }\end{array}$ & $\begin{array}{l}\text { SDBS(0.125 } \\
\text { wt.\%) }\end{array}$ & $\begin{array}{l}\text { Vibrating } \\
\text { U-tube }\end{array}$ & $\rho \uparrow$ \\
\hline Vallejo et al. [38] & $\begin{array}{l}\text { Functionalized } \\
\text { graphene nanoplatelets }\end{array}$ & $0.25-1$ wt. $\%$ & $\begin{array}{l}\text { Propylene glycol: } \\
\text { water (30:70) }\end{array}$ & No surfactant & $\begin{array}{l}\text { Vibrating } \\
\text { U-tube }\end{array}$ & $\rho \uparrow, \alpha_{\mathrm{p}} \downarrow$ \\
\hline Vallejo et al. [39] & $\begin{array}{l}\text { Functionalized } \\
\text { graphene nanoplatelets }\end{array}$ & $0.25-1$ wt. $\%$ & $\begin{array}{l}\text { Havoline }{ }^{\circledR} \text { XLC } \\
\text { Premixed 50/50, }\end{array}$ & $\begin{array}{l}\text { SDBS(0.125 } \\
\text { wt.\%) }\end{array}$ & $\begin{array}{l}\text { Vibrating } \\
\text { U-tube }\end{array}$ & $\rho \uparrow, \alpha_{\mathrm{p}} \downarrow$ \\
\hline Yarmad et al. [40] & $\begin{array}{l}\text { Functionalized } \\
\text { graphene nanoplatelets }\end{array}$ & $0-0.1$ wt. $\%$ & Water & No surfactant & $\begin{array}{l}\text { Vibrating } \\
\text { U-tube }\end{array}$ & $\rho \uparrow$ \\
\hline Yarmand et al. [41] & $\begin{array}{l}\text { Activate } \\
\text { carbon/graphene hybrid }\end{array}$ & $\begin{array}{l}0.02,0.04 \\
0.06 \text { wt. } \%\end{array}$ & Ethylene glycol & No surfactant & $\begin{array}{l}\text { Vibrating } \\
\text { U-tube }\end{array}$ & $\rho \uparrow$ \\
\hline
\end{tabular}

Azizi et al. [34] studied the density of ethylene glycol-based and water-based nanofluids containing 0.025-0.1 wt.\% of polyvinyl alcohol-functionalized few-layer graphene. Results in the temperature range from 293.15 to $323.15 \mathrm{~K}$ showed as density increased with nanoparticle loading and declines with temperature $(\sim 0.98 \%$ for the $0.1 \mathrm{wt} . \%$ aqueous nanofluid in the whole studied temperature range). Ijam et al. [35] investigated the density of graphene oxide nanosheet dispersions in an ethylene glycol:water mixture at 40:60 mixing ratio. In the analyzed nanoparticle (0.01-0.1 wt.\%) and temperature (298.15-318.15 K) ranges density decreased with the addition of the nanoparticles, with maximum reductions $1-1.13 \%$ for the highest nanoparticle concentration. Vallejo et al. [39] and Sani et al. [37] investigated the volumetric behavior of polycarboxylate chemically modified graphene nanoplatelet dispersions based on a commercial coolant, Havoline ${ }^{\circledR}$ XLC Premixed 50/50. In both studies, a concentration of $0.125 \mathrm{wt} . \%$ of SDBS was used to improve nanofluid stability. Density measurements showed as density increased with nanoparticle concentration, up to $0.37-0.58 \%$ for the $1 \mathrm{wt} . \%$ in the temperature range from 293.15 to $343.15 \mathrm{~K}$ [39]. Yarmand et al. [40] analyzed the density of water-based nanofluids loaded with $0.02-0.1 \mathrm{wt} . \%$ of graphene nanoplatelets functionalized using nitric and sulfuric acid. In the studied temperature range (from 293.15 to $313.15 \mathrm{~K}$ ) a maximum increase of $0.06 \%$ was observed for the $0.1 \mathrm{wt} . \%$ at $313.15 \mathrm{~K}$.

Here, nanofluids were prepared with few-layer graphene (FLG). Tyfocor ${ }^{\circledR}$ LS, a commercial fluid which is a mixture of propylene-glycol/water (around 40:60 $\mathrm{wt} \%$ ) was used as base fluid [42,43] and 
three different surfactants (Triton X-100, Pluronic ${ }^{\circledR}$ P-123 and Gum Arabic) were used to help in the dispersion and stabilization of FLG in the base fluid and to counterbalance hydrophobic attractive forces. The concentrations of nanoparticles in these nanofluids were $0.05,0.1,0.25$ and $0.5 \mathrm{wt} . \%$. The nanoparticle:surfactant ratio added was fixed to 1:2. Density, isobaric thermal expansivity and surface tension of all base fluids and nanofluids were evaluated between 283.15 and $323.15 \mathrm{~K}$. These properties and their evolutions are finally discussed according to the temperature dependence, concentration and the used type of surfactant and the nanoparticle content. This will complete the thermal conductivity evaluation of these nanofluids recently performed in [44].

\section{Materials and Methods}

\subsection{Nanofluid Preparation}

As recently described in [44], FLG was synthesized by a mechanical exfoliation method. Typically, $400 \mathrm{mg}$ of expanded graphite (provided by Mersen, France) was sonicated by using a Branson probe sonicator $(80 \mathrm{~W}, 4 \mathrm{~h}, 298.15 \mathrm{~K})$ in water in the presence of tannic acid (Sigma-Aldrich). The prepared FLG was thereafter washed typically 5 times with deionized water before being freeze-dried. The obtained FLG powder was added to different base fluids prepared by adding the chosen amount of surfactant to Tyfocor ${ }^{\circledR}$ LS used as solvent. Tyfocor ${ }^{\circledR}$ LS was kindly provided by Viessmann S.A. Three different nonionic surfactants were used: Triton $\mathrm{X}-100\left(\mathrm{C}_{8} \mathrm{H}_{17} \mathrm{C}_{6} \mathrm{H}_{4}\left(\mathrm{OC}_{2} \mathrm{H}_{4}\right)_{9-10} \mathrm{OH}\right)$, Pluronic ${ }^{\circledR}$ P-123 -a linear triblock copolymer comprising poly(ethylene oxide) (PEO) and poly(propylene oxide) (PPO) alternating blocks such as PEO-PPO-PEO- and Gum Arabic (natural mixture of polysaccharides and glycoproteins). The nanofluid of the highest FLG concentration ( $0.5 \mathrm{wt} . \%)$ was first prepared by adding the desired amount of FLG powder in the surfactant+Tyfocor ${ }^{\circledR}$ LS-based fluid and dispersing the mixture with a Bioblock Scientific VibraCell 75,042 probe sonicator ( $125 \mathrm{~W}$ with a pulse mode $2 \mathrm{~s}$ ON/1 s OFF) by 5 runs of $15 \mathrm{~min}$. This concentrated nanofluid was then diluted with Tyfocor ${ }^{\circledR}$ LS to obtain the nanofluids with different FLG concentrations of $0.05,0.1$ and $0.25 \mathrm{wt} . \%$.

\subsection{Characterization Techniques}

An XL30 S-FEG apparatus (Philips, Netherlands) was used for scanning electron microscopy (SEM) observations. High-resolution transmission electron microscopy (HRTEM) investigations were performed thanks to a JEM-ARM 200F apparatus (JEOL, Japan) at $80 \mathrm{kV}$. For both SEM and TEM observations, the FLG powder was dispersed in ethanol and deposited in the dedicated sample holder. Holey carbon grids (200 mesh size) were used for TEM. For each sample, about 30 images were taken at different areas to guarantee a statistical description of the sample.

Density, $\rho$, of Tyfocor ${ }^{\circledR}$ LS, liquid Triton X-100, each surfactant+Tyfocor ${ }^{\circledR}$ LS mixture used as base fluids and the prepared FLG-based nanofluids were experimentally determined by means of a density meter DMA 501 (Anton Paar, Austria). The measurement principle is based on the oscillating U-tube technique. The density measurements were carried out in the temperature range from 288.15 to $313.15 \mathrm{~K} .2 \mathrm{~mL}$ of each sample were withdrawn into a syringe and then released in the U-tube until the tube was completely full. Careful rinsing with ethanol and acetone was performed at the end of each measurement. Between each series of measurements, the densimeter was carefully checked by measuring air and distilled water densities at $293.15 \mathrm{~K}$. The absolute average deviations (AAD) between the experimental results of distilled water at $293.15 \mathrm{~K}$ and literature data [45] were less or equal to $0.02 \%$. The estimated uncertainty of the density determinations was lower than $1 \mathrm{~kg} \cdot \mathrm{m}^{-3}$. During density measurements with DMA500 densimeter, temperature was controlled within an accuracy of $\pm 0.3 \mathrm{~K}$ (repeatability of $\pm 0.1 \mathrm{~K}$ ) using cascaded Peltier elements integrated in the U-tube vibrating cell.

A Drop Shape Analyzer DSA-30 from KRÜSS GmBH (Hamburg, Germany) was used to perform the ST measurements. Drops of samples were produced with a 15-gauge needle (outer diameter of $1.835 \mathrm{~mm}$ ) controlling the flow rate and volume. The entire followed experimental procedure was described in detail in refs. $[5,46]$. With pendant drop technique, ST was determined from the 
density of each sample and the drop shape analysis suspended to the extremity of the needle, using Young-Laplace equation. In the following, each reported ST value was calculated from the average of at least 10 measurements. ST of distilled water was measured in the 283.15-333.15 K temperature range [42]. The uncertainty with this equipment is low and an AAD of $1.1 \%$ was obtained between the experimental data of water and reference data in this temperature range [45]. Regarding surface tension experiments, samples were thermostatized with a precision of $\pm 0.2 \mathrm{~K}$ by means of a TC40 environmental chamber in which temperature is regulated using a Peltier system and monitored by a PT100 probe. It should be also noted that a series of ST experiments at ambient temperature has been previously performed by varying the surfactant content to determine the adsorption phenomenon of these surfactants in Tyfocor ${ }^{\circledR}$ LS and the critical micelle concentration (CMC). This is useful for the discussion about the influence of surfactant and FLG content on the ST of nanofluids.

\section{Results and Discussion}

\subsection{FLG Nanosheets Characterization}

Figure 1 shows images from both SEM and TEM observations of FLGs used in this work. They appear as nanosheets of around $5 \mu \mathrm{m}$ in lateral size (Figure 1a). From TEM observations at low magnification, very thin layers deposited on the holed TEM carbon grid are visible (Figure 1b). Their thickness, if of only a few layers of graphene, as it is observed in Figure $1 \mathrm{c}$ and its insert, are consistent with the graphene nomenclature [47]. The hexagonal lattice of the graphene layer well noticeable in high TEM magnification image is the sign of the high structural quality of the used FLGs (Figure 1d).

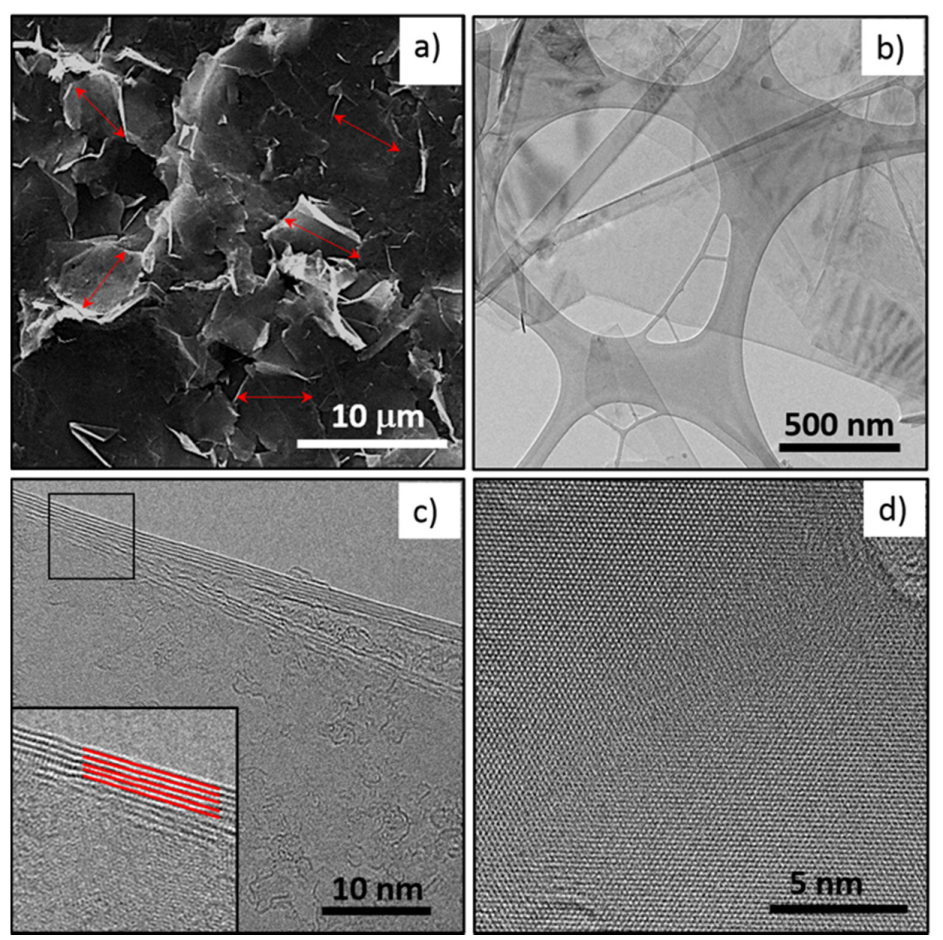

Figure 1. SEM and TEM observations of the used few-layer graphene (FLG). (a) SEM image, (b-d) TEM images at different magnifications.

\subsection{Density}

Surface tension and isobaric thermal expansivities are related to the density of fluids. This is the reason why it is important to determine this property first determined. The densities of each of the base fluids and nanofluids were experimentally evaluated from 288.15 to $313.15 \mathrm{~K}$ in intervals 
of $5 \mathrm{~K}$. First, the experimental densities for Tyfocor ${ }^{\circledR}$ LS showed an AAD of $0.13 \%$ in comparison to manufacturer data [48].

The experimental density values were correlated to Equation $(1)[38,42,49]$ to obtain the density values for all samples below 288.15 and above $313.15 \mathrm{~K}$.

$$
\rho(\mathrm{T})=\mathrm{a}_{0}+\mathrm{a}_{1} T+\mathrm{a}_{2} T^{2}
$$

where $\rho$ is the density in $\mathrm{kg} . \mathrm{m}^{-3}$ and $T$ is the temperature in $\mathrm{K}$. Densities at 283.15 and $323.15 \mathrm{~K}$ were calculated using this equation. $a_{i}$ coefficients of each sample are gathered in Table 3 along with their respective standard deviation.

Table 3. Fitting parameters $a_{i}$ and standard deviations (St. Dev.) from Equation (1) for the base fluids and nanofluids with Triton X-100, Pluronic ${ }^{\circledR}$ P-123, and Gum Arabic as surfactant for different mass fractions.

\begin{tabular}{|c|c|c|c|c|c|c|c|c|c|}
\hline \multirow[b]{2}{*}{$\varphi_{\mathrm{m}, \mathrm{sft}}(\%)$} & \multicolumn{2}{|l|}{ Tyfocor ${ }^{\circledR}$ LS } & \multicolumn{2}{|c|}{ Base Fluids } & \multirow[b]{2}{*}{1.0} & \multicolumn{4}{|c|}{ Nanofluids } \\
\hline & 0 & 0.1 & 0.2 & 0.5 & & 0.1 & 0.2 & 0.5 & 1.0 \\
\hline$\varphi_{\mathrm{m}, \mathrm{np}}(\%)$ & 0 & 0 & 0 & 0 & 0 & 0.05 & 0.1 & 0.25 & 0.5 \\
\hline \multicolumn{10}{|c|}{ FLG nanofluids based on Tyfocor ${ }^{\circledR}$ LS and Triton X-100 } \\
\hline $\mathrm{a}_{0} / \mathrm{kg} \cdot \mathrm{m}^{-3}$ & 1043.8 & 1038.3 & 1038.4 & 1005.5 & 1005.7 & 991.41 & 1007.5 & 1021.4 & 987.16 \\
\hline$\left(\mathrm{a}_{1}\right) / \mathrm{kg} \cdot \mathrm{m}^{-3} \cdot \mathrm{K}^{-1}$ & 0.53736 & 0.57746 & 0.57689 & 0.79449 & 0.79449 & 0.87035 & 0.76469 & 0.67879 & 0.91615 \\
\hline$\left(10^{3} \cdot \mathrm{a}_{2}\right) / \mathrm{kg} \cdot \mathrm{m}^{-3} \cdot \mathrm{K}^{-2}$ & -1.93 & -2.00 & -2.00 & -2.36 & -2.36 & -2.46 & -2.29 & -2.14 & -2.54 \\
\hline$\left(10^{2}\right.$.St. Dev. $) / \mathrm{kg} \cdot \mathrm{m}^{-3}$ & 3.6 & 1.8 & 2.0 & 2.3 & 2.3 & 0.8 & 3.4 & 1.8 & 0.8 \\
\hline \multicolumn{10}{|c|}{ FLG nanofluids based on Tyfocor ${ }^{\circledR}$ LS and Pluronic ${ }^{\circledR}$ P-123 } \\
\hline $\mathrm{a}_{0} / \mathrm{kg} \cdot \mathrm{m}^{-3}$ & 1043.8 & 1070 & 1012.5 & 1041.3 & 1044.1 & 1044.7 & 990.15 & 1008.8 & 1012.1 \\
\hline$\left(\mathrm{a}_{1}\right) / \mathrm{kg} \cdot \mathrm{m}^{-3} \cdot \mathrm{K}^{-1}$ & 0.53736 & 0.36499 & 0.74983 & 0.55741 & 0.54941 & 0.5107 & 0.87577 & 0.76411 & 0.75897 \\
\hline$\left(10^{3} \cdot \mathrm{a}_{2}\right) / \mathrm{kg} \cdot \mathrm{m}^{-3} \cdot \mathrm{K}^{-2}$ & -1.93 & -1.64 & -2.29 & -1.96 & -1.96 & -1.86 & -2.46 & -2.29 & -2.29 \\
\hline$\left(10^{2}\right.$. St. Dev. $) / \mathrm{kg} \cdot \mathrm{m}^{-3}$ & 3.7 & 1.8 & 1.8 & 2.1 & 1.9 & 1.9 & 0.9 & 2.2 & 2.1 \\
\hline \multicolumn{10}{|c|}{ FLG nanofluids based on Tyfocor ${ }^{\circledR}$ LS and Gum Arabic } \\
\hline $\mathrm{a}_{0} / \mathrm{kg} \cdot \mathrm{m}^{-3}$ & 1043.8 & 1037.1 & 1029.3 & 1022.8 & 1041.9 & 1013.3 & 988.12 & 977.14 & 1003.7 \\
\hline$\left(\mathrm{a}_{1}\right) / \mathrm{kg} \cdot \mathrm{m}^{-3} \cdot \mathrm{K}^{-1}$ & 0.53736 & 0.5826 & 0.64217 & 0.68855 & 0.57746 & 0.72345 & 0.89554 & 0.98172 & 0.8294 \\
\hline$\left(10^{3} \cdot \mathrm{a}_{2}\right) / \mathrm{kg} \cdot \mathrm{m}^{-3} \cdot \mathrm{K}^{-2}$ & -1.93 & -2.00 & -2.11 & -2.18 & -2.00 & -2.21 & -2.50 & -2.64 & -2.39 \\
\hline$\left(10^{2}\right.$.St. Dev. $) / \mathrm{kg} \cdot \mathrm{m}^{-3}$ & 3.7 & 1.1 & 2.1 & 1.5 & 1.8 & 2.7 & 0.4 & 0.9 & 3.2 \\
\hline
\end{tabular}

Figure 2 shows the variation of the density of the nanofluids and base fluids measured and extrapolated with Equation (1) for the three surfactant series. The density of both base fluids and the corresponding nanofluids decreases by $2.4 \%$ between 283.15 and $323.15 \mathrm{~K}$ with a similar trend. Except for addition of 0.5 and $1 \mathrm{wt} . \%$ of Gum Arabic in Tyfocor ${ }^{\circledR}$ LS for which the density increases by 0.18 and $0.36 \%$, respectively, addition of surfactant has no significant effect on the density evolution compared to Tyfocor ${ }^{\circledR}$ LS alone.

The effect that the addition of FLG has on the density of the base fluids (i.e., corresponding Tyfocor ${ }^{\circledR}$ LS-surfactant mixtures) is shown in Figure 3. The results show that the nanofluid density decreases slightly for the lowest FLG concentrations and increases for the highest FLG concentration studied. Results are similar for the three studied nanofluid sets, with average deviations of the density obtained at all temperatures for the four concentrations $(0.05,0.1,0.25$, and $0.5 \mathrm{wt} . \%)$ around -0.08 , $-0.05,0.05$, and $0.2 \%$, respectively. The decrease in density after adding a small amount of FLG to the base fluids could be explained by the existence of a negative excess volume, which represents a deviation from the ideal mixing volume. The FLG nanosheets (relatively big compared to the surrounding fluid molecules) may indeed impact the local organization of the base fluid molecules which are much more packed together than in the pure base fluid, resulting in the observed decrease in density $[50,51]$. A contractive volumetric behavior was also reported for aqueous nanofluids of $\mathrm{CuO}$ [52] or $\mathrm{Al}_{2} \mathrm{O}_{3}$ [53], for $\mathrm{ZnO}$ suspensions in a mixture of ethylene glycol and water [54] or for polyethylene glycol (PEG)-based nanofluids of $\mathrm{Fe}_{3} \mathrm{O}_{4}$ coated with oleic acid-PEG [55], for instance. 
The results of both the base fluids and the nanofluids were compared with the values calculated the weight-average equation, Equation (2) [56]:

$$
\frac{1}{\rho_{n f}}=\frac{\varphi_{m, n p}}{\rho_{n p}}+\frac{\varphi_{m, s f t}}{\rho_{s f t}}+\frac{1-\varphi_{m, n p}-\varphi_{m, s f t}}{\rho_{b f}}
$$

where $\rho$ is the density, $\varphi_{m}$ is the mass fraction and $n f, n p$, sft and $b f$ are subscripts for the nanofluid, the nanoparticles (e.g., FLG), the used surfactant and the corresponding base fluid, respectively. Density of Triton X-100 was also measured as this surfactant is under a liquid form in the studied temperature range, while the density values of Pluronic ${ }^{\circledR}$ P-123 and Gum Arabic at ambient temperature were $1040 \mathrm{~kg} \cdot \mathrm{m}^{-3}$ and $1400 \mathrm{~kg} \cdot \mathrm{m}^{-3}$, respectively, as taken from the literature [57,58]. The density of FLG powder measured at ambient temperature using a gas pycnometer AccPyc 1330 (micromeritics) was determined to be $1820 \mathrm{~kg} \cdot \mathrm{m}^{-3}$. Density of Pluronic ${ }^{\circledR}$ P-123, Gum Arabic and FLG nanoparticles is assumed to not depend on the temperature in the studied range. 


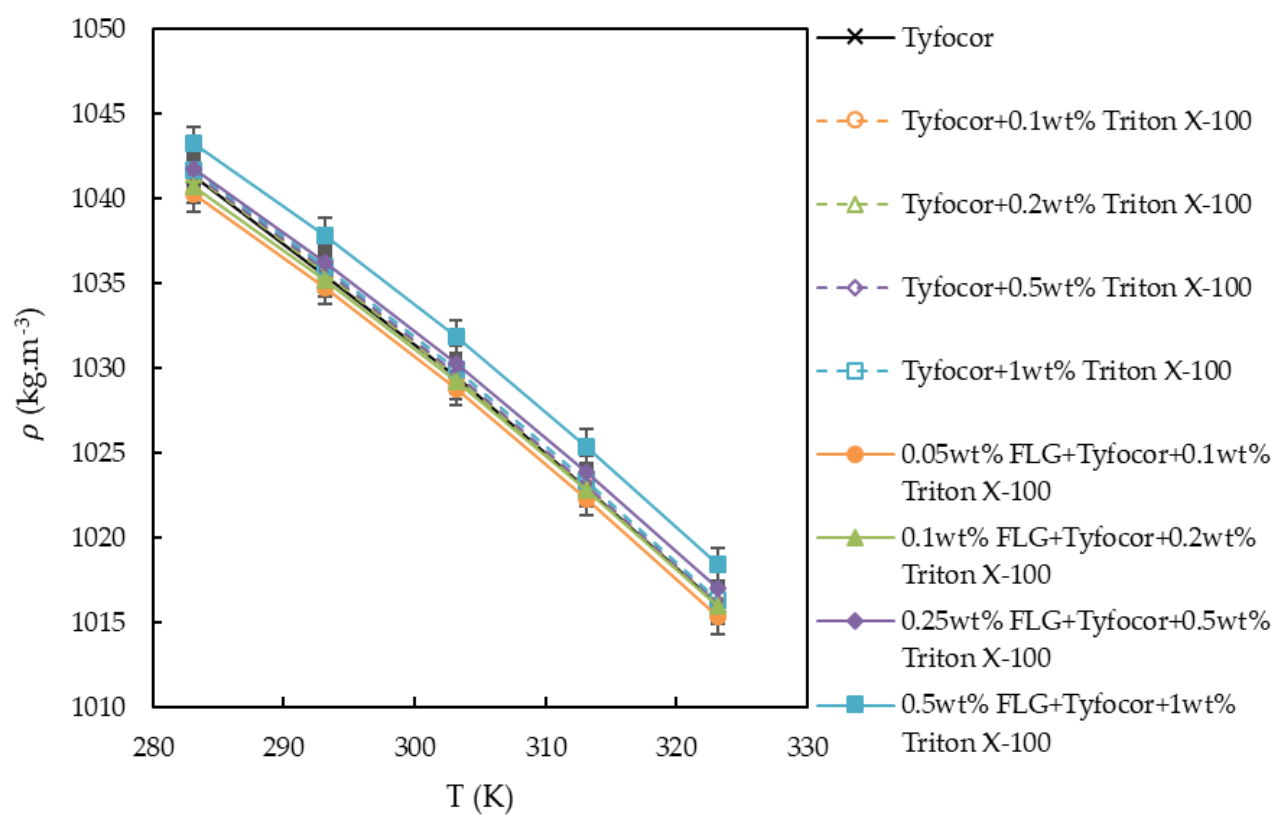

(a)

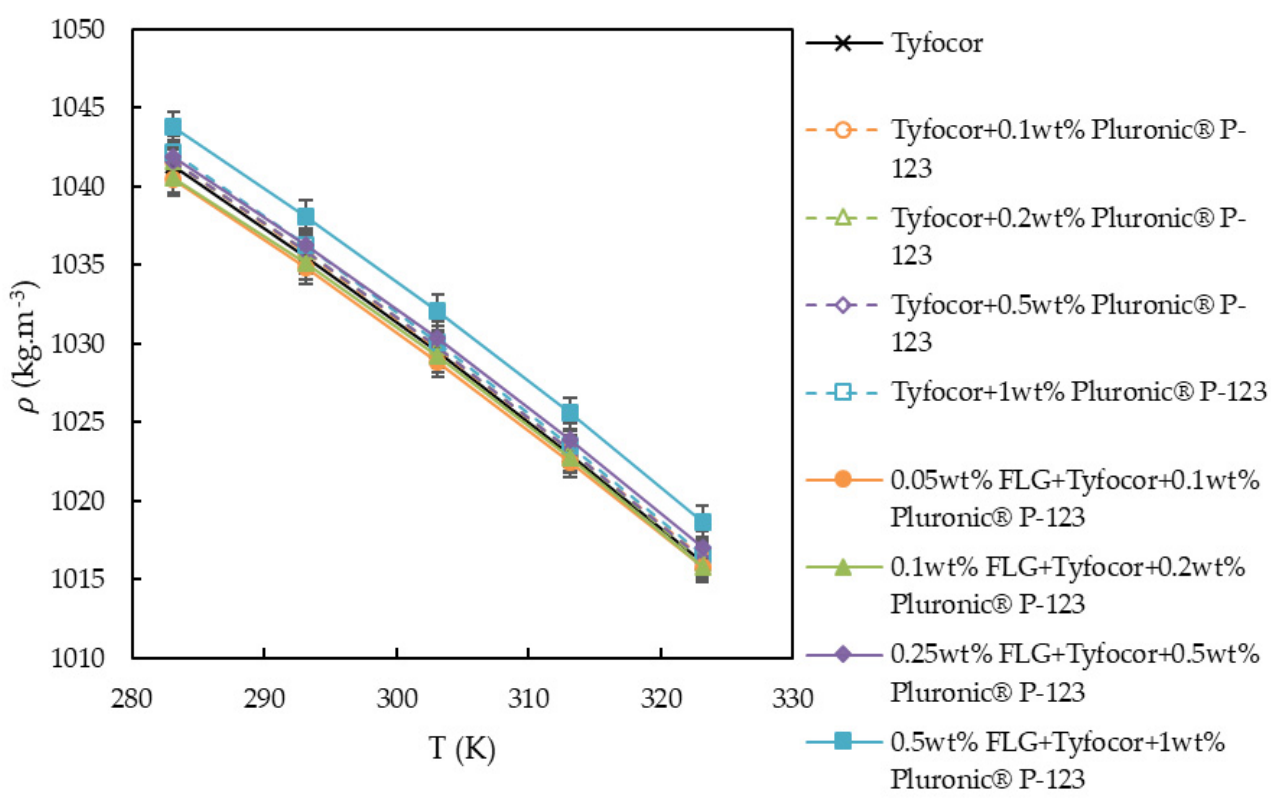

(b)

Figure 2. Cont. 


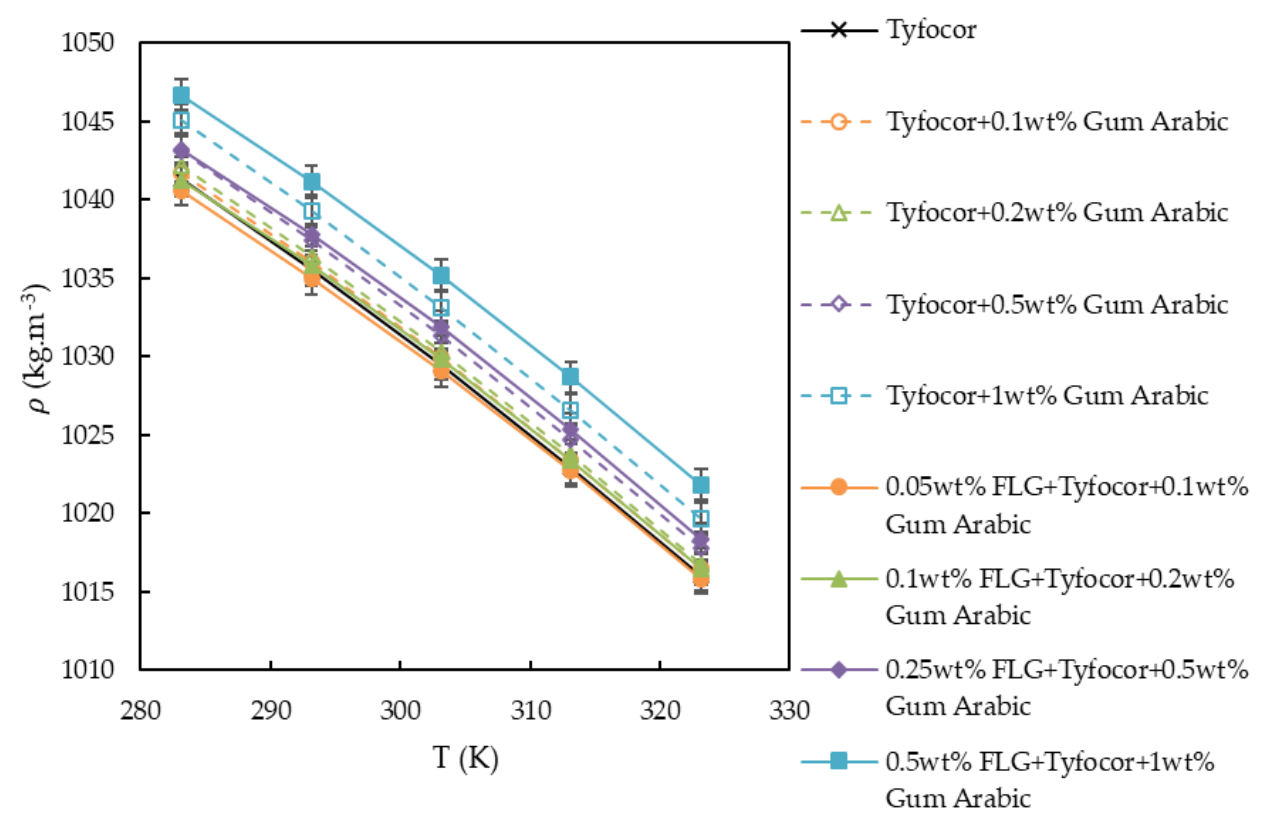

(c)

Figure 2. Density of FLG-based nanofluids and the corresponding base fluids against temperature prepared with (a) Triton X-100, (b) Pluronic ${ }^{\circledR}$ P-123 and (c) Gum Arabic.

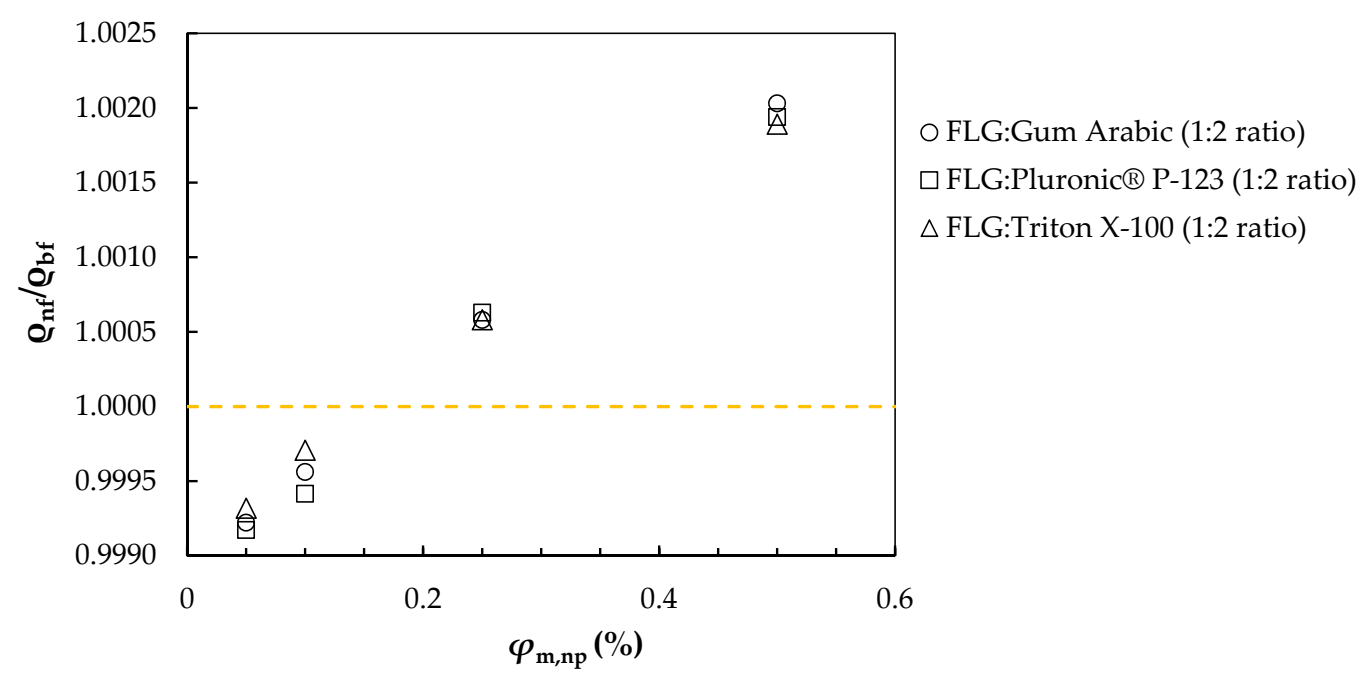

Figure 3. Relative density of nanofluids, which is defined as the ratio of the nanofluids density to the corresponding base fluids density (Tyfocor ${ }^{\circledR}$ LS-surfactant mixtures), as a function of FLG mass concentration at $303.15 \mathrm{~K}$.

By comparing the densities calculated using Equation (2) with the experimental values for the samples (base fluids and nanofluids), an AAD of $0.02 \%, 0.009 \%$ and $0.01 \%$ was obtained for the samples prepared with Triton X-100, Pluronic ${ }^{\circledR}$ P-123, and Gum Arabic, respectively, leading to a good agreement. Since the densities of the FLG nanoparticles and the three surfactants are higher than the density of the Tyfocor ${ }^{\circledR}$ LS, according to Equation (2), this property should increase with both surfactant and FLG concentration. This behavior does not agree with the slight volumetric contraction experimentally observed for the two lowest nanoparticle concentrations $(0.05$ and $0.1 \mathrm{wt} . \%$ contents of FLG). However, maximum deviations for these two concentrations are in the $0.06-0.10 \%$ range which are slightly lower or closer to the uncertainty of the experimental device $(0.1 \%)$. 


\subsection{Isobaric Thermal Expansivity}

From the data gathered in Table 3, the effects of temperature, nature and concentration of the surfactant, as well as FLG mass concentration on the isobaric thermal expansivity, $\alpha_{p},[38,54,59]$ is evaluated according to the following equation, Equation (3):

$$
\alpha_{p}-\frac{1}{\rho}\left(\frac{\partial \rho}{\partial T}\right)_{p}
$$

Figure 4 shows that $\alpha_{p}$ increases when the temperature rises. In the case of Tyfocor ${ }^{\circledR}$ LS alone, this increase is about $11 \%$ across the $293.15-308.15 \mathrm{~K}$ temperature interval. The results show also that the addition of surfactant to Tyfocor ${ }^{\circledR}$ LS has no effect on their isobaric thermal expansivity with no significant difference between the three used surfactants, except a slight increase, about $1.4 \%$ for the highest weight concentration of Pluronic ${ }^{\circledR}$ P123 (1 wt.\%). In contrast to the base fluids, a decrease in $\alpha_{p}$ of all the used base fluids was observed in the presence of FLG; the reduction rate decreases from 2.9 to $1.8 \%$ in the case of Triton X-100, from 3.4 to $1.9 \%$ for nanofluids with Pluronic ${ }^{\circledR}$ P-123 and from 3.4 to $1.4 \%$ in the case of Gum Arabic, without any significant difference between the four FLG concentrations.

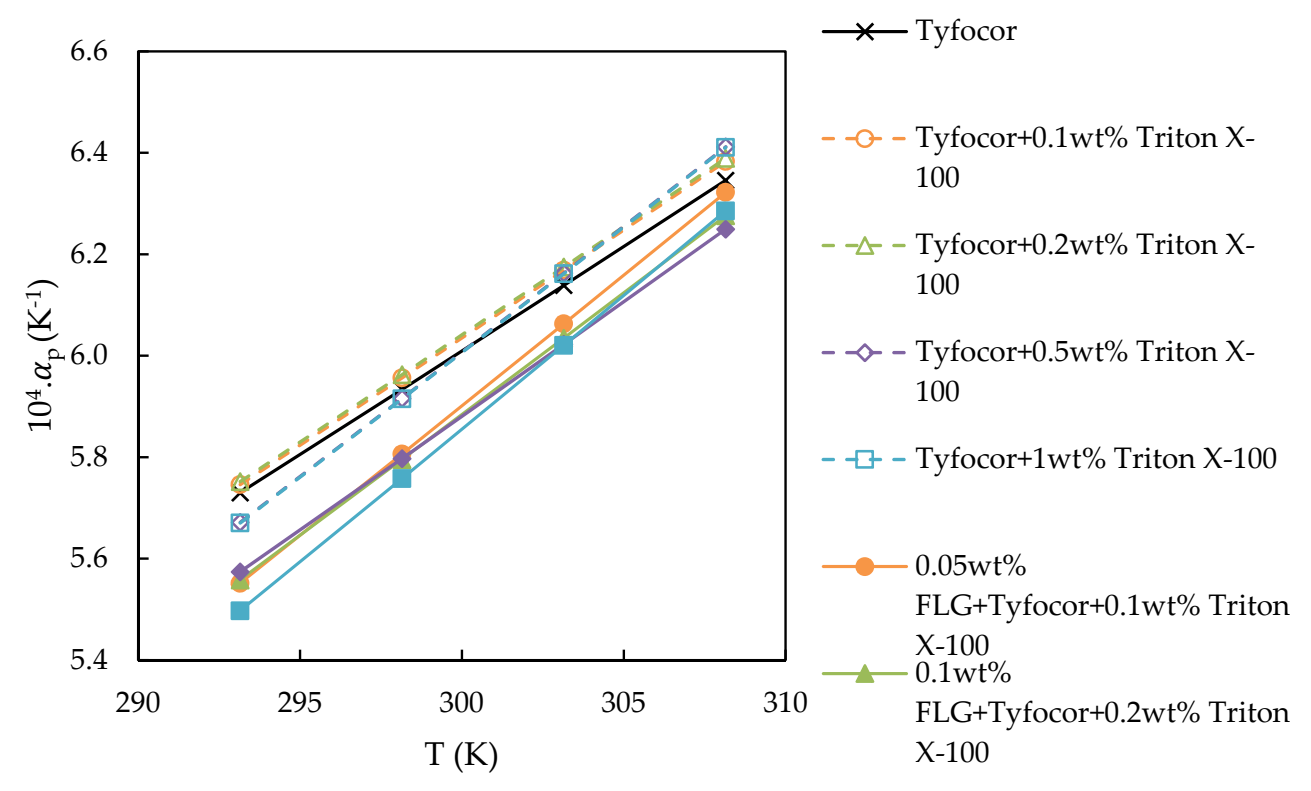

(a)

Figure 4. Cont. 


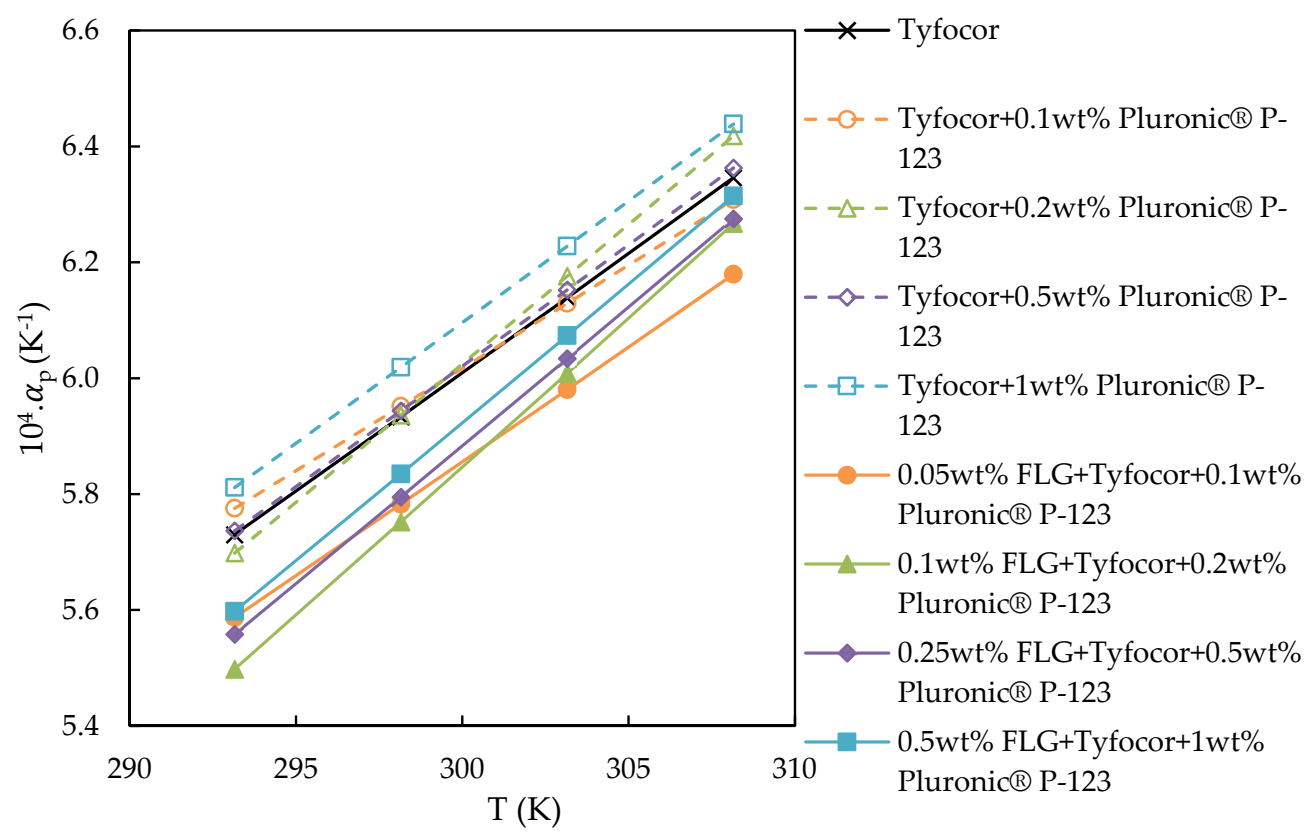

(b)

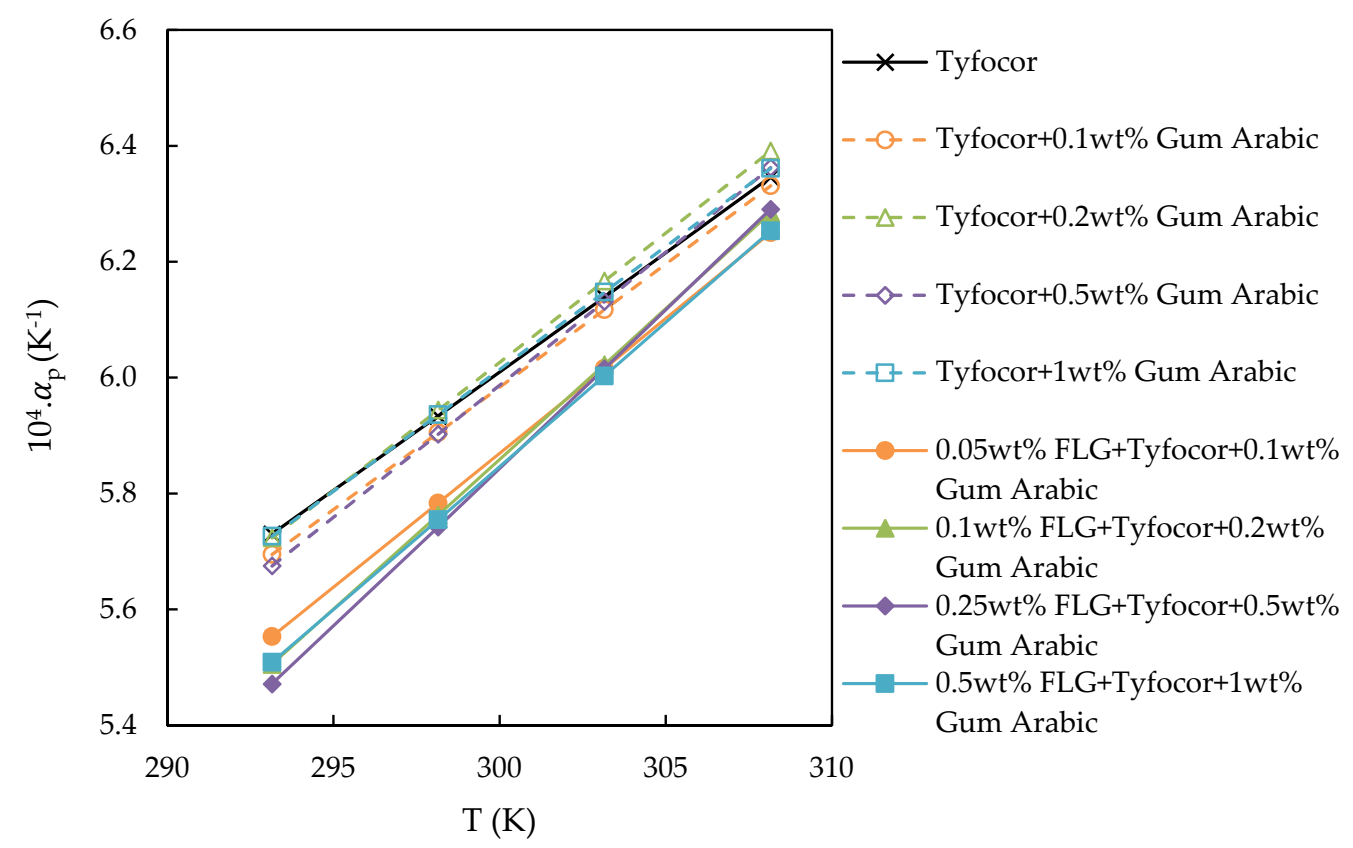

(c)

Figure 4. Variation of the isobaric thermal expansivity, $\alpha_{p}$, as a function of temperature of both base fluids and nanofluids series prepared with (a) Triton X-100, (b) Pluronic ${ }^{\circledR}$ P-123 and (c) Gum Arabic.

The increase of $\alpha_{p}$ of nanofluids with temperature may be the indication that nanostructured fluids undergo a minor degree of cohesion when compared to base fluids. This behavior agrees with the work reported by Vallejo et al. [38], although with a lower increase in $\alpha_{p}$ with the temperature for their functionalized graphene nanoplatelets (fGnP)/propylene glycol:water (PG:W) (30:70) wt.\% 
nanofluids between 303.15 and $313.15 \mathrm{~K}$, and a decrease in $\alpha_{p}$. with increasing fGnP content were observed. In the literature, the dependence of $\alpha_{p}$. with the addition of nanoparticles showed dissimilar results. Cabaleiro et al. [60] investigated ethylene glycol-based nanofluids containing two different nanocrystalline structures of titanium dioxide. They observed that $\alpha_{p}$. of these nanofluids exhibited similar values to those of the corresponding base fluid with only a small decrease in $\alpha_{p}$. reported for the nanofluids. Korolovych et al. [61] also found a decreasing trend with the nanoparticle concentration in the isobaric thermal expansivity for single-walled carbon nanotubes/water nanofluids at different temperature and pressure conditions. In addition, Cabaleiro et al. [54] showed a continuous decrease in $\alpha_{p}$. that reached $18 \%$ with the increasing content of $\mathrm{ZnO}$ nanoparticles in ethylene glycol:water mixture up to $10 \mathrm{wt} . \%$ at various temperatures and pressures. On the contrary, a significant increase in the isobaric thermal expansivity was reported by Nayak et al. [62,63] of up to $27.2 \%$ with respect to the base fluid in the case of water-based $\mathrm{CuO}, \mathrm{TiO}_{2}, \mathrm{Al}_{2} \mathrm{O}_{3}$, and $\mathrm{SiO}_{2}$ nanofluids. They obtained $\alpha_{p}$. values thanks to an experimental setup that measured the bulk variation with temperature in a glass flask with a calibrated stem. Further studies on this property are required to clarify the role of each parameter and its precise impact on isobaric thermal expansivity of the nanofluids, especially those based on propylene glycol-water mixtures such as commercial Tyfocor ${ }^{\circledR}$ LS.

\subsection{Surface Tension}

Fluid ST is an important property to be investigated since it plays an important role in many heat transfer configurations and processes, as emphasized by Estellé et al. [23]. ST measurements of base fluids and nanofluids at the four FLG concentrations, in a temperature range of 283.15-323.15 K for the Tyfocor ${ }^{\circledR}$ LS-based nanofluids, are reported in Figure 5. As explained before, necessary density values were experimentally evaluated (in the temperature range between 293.15 and $313.15 \mathrm{~K}$ ) and calculated using Equation (1) for both lower and higher temperatures. The error bars were determined from the standard deviation to the average value of ST.

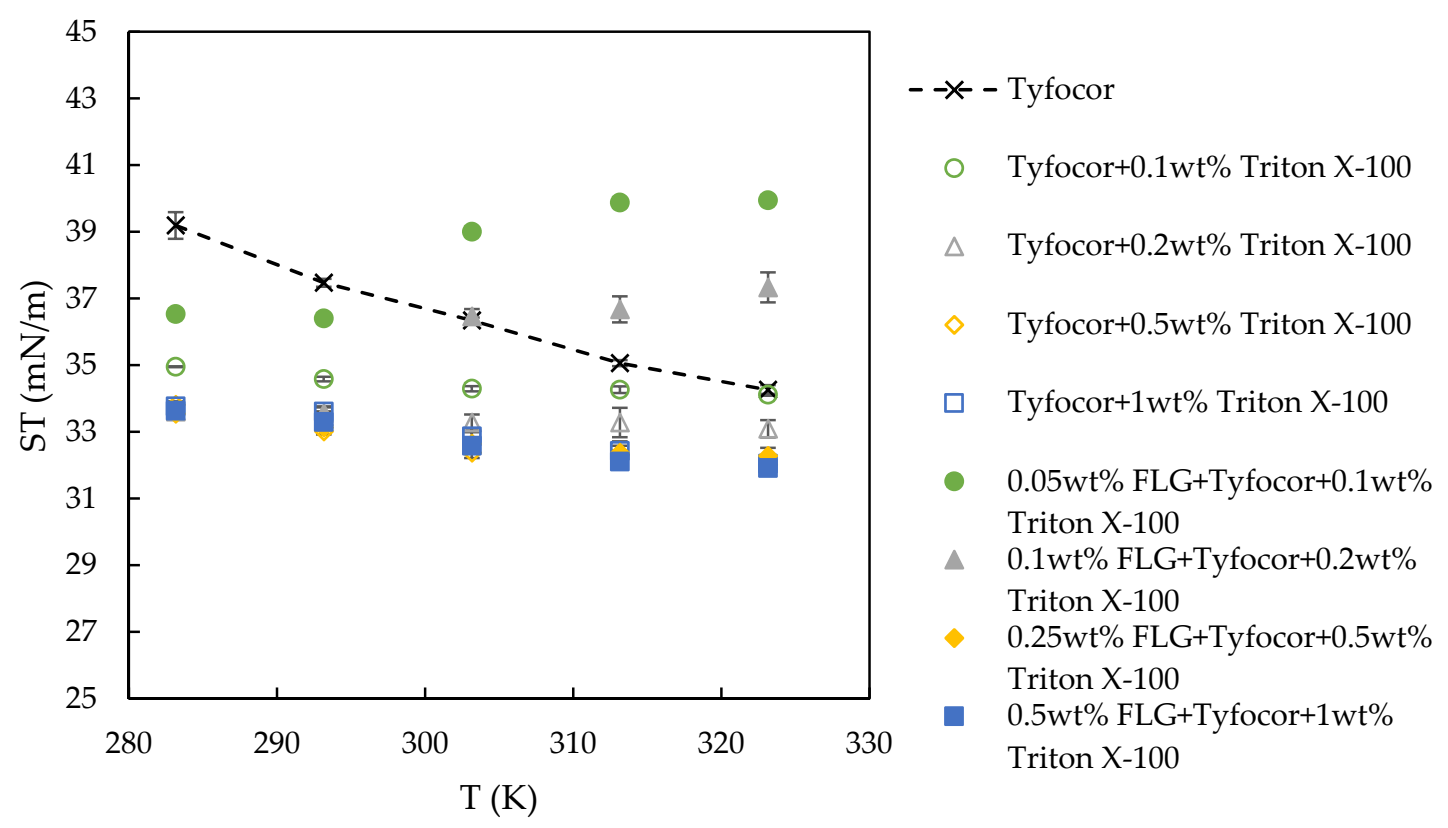

(a)

Figure 5. Cont. 


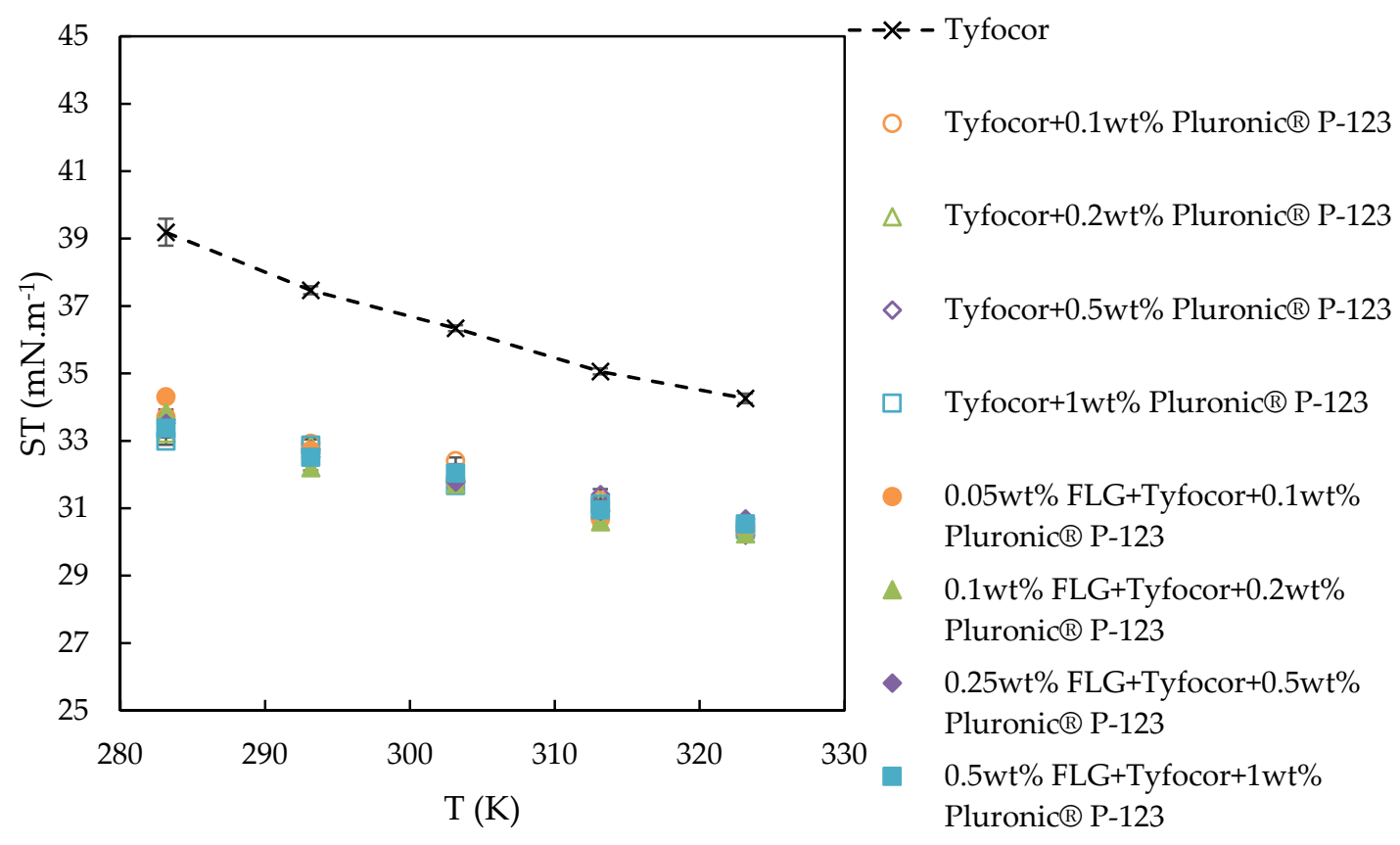

(b)

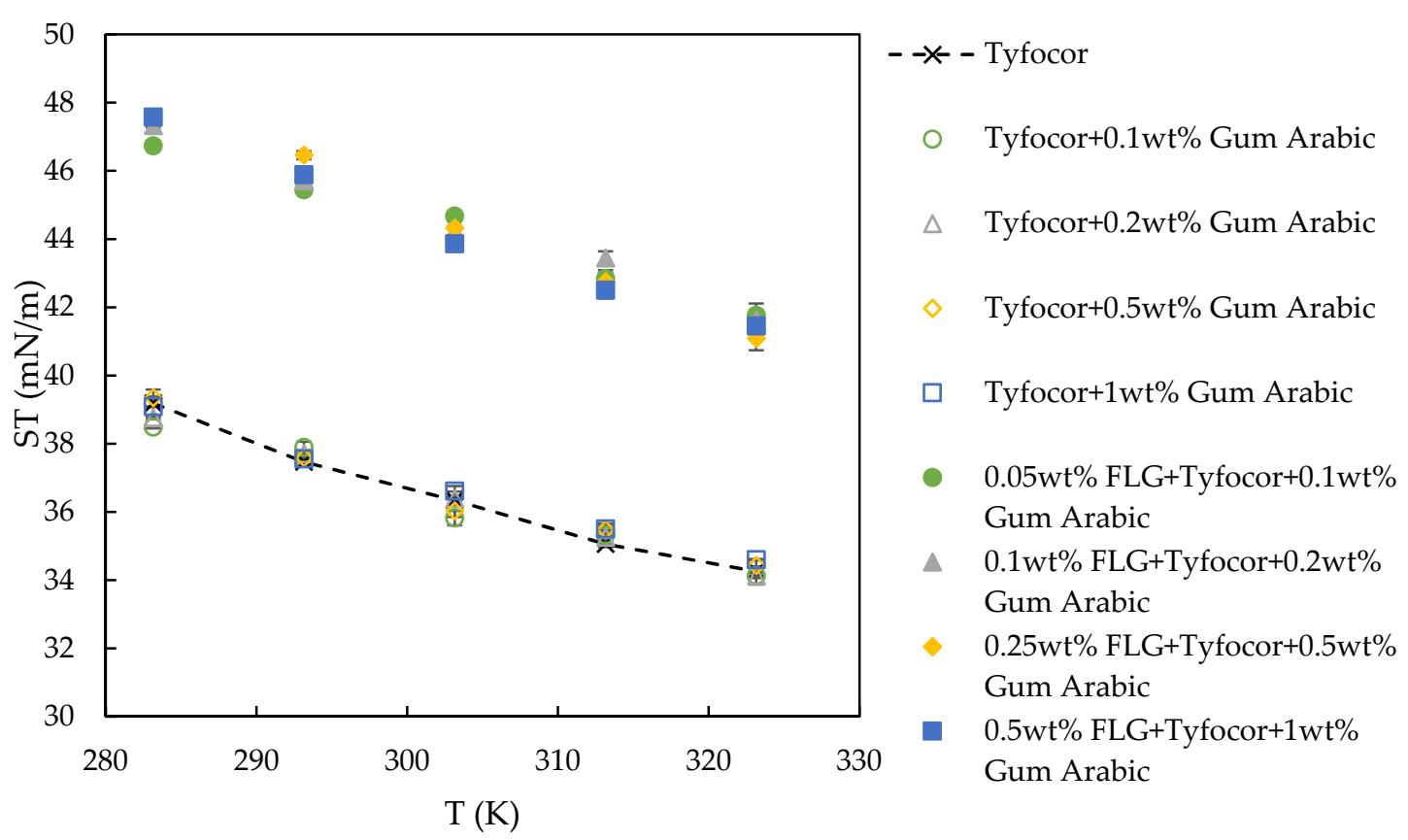

(c)

Figure 5. Evolution of surface tension (ST) of the FLG nanofluids prepared with (a) Triton X-100, (b) Pluronic ${ }^{\circledR}$ P-123 and (c) Gum Arabic as a function of temperature. Dashed lines are drawn to guide the eyes.

The results about ST are presented and discussed below considering the effect of surfactant, temperature and nanoparticle addition. Before that, in order to clearly distinguish in the following the 
effect of surfactant and the FLG presence on the ST evolution of FLG-based nanofluids, the variation of ST of each base fluid with surfactant content was measured to possibly evaluate the adsorption phenomenon of these surfactants in Tyfocor ${ }^{\circledR}$ LS. The addition of a surfactant into a liquid generally reduces the interfacial tension since the presence of the surfactant leads to adsorption at gas-liquid interface, and the rate of reduction depends on the surfactant type and concentration in the solution. It is well admitted that the CMC of a surfactant within a liquid can be determined at the inflexion point of the decreasing value and the plateau of ST with the increase in surfactant content. The surface tension of some samples may continue slightly decreasing even beyond the $\mathrm{CMC}$, as reported by Radulovic et al. [64] for Triton X-100 aqueous solutions. The CMC of surfactants in Tyfocor ${ }^{\circledR}$ LS experimentally determined in this work at ambient temperature was found around 0.01 and $0.2 \mathrm{wt} . \%$ for Pluronic ${ }^{\circledR}$ P-123 and for Triton X-100, respectively. No significant change was noticed for Gum Arabic in the range $0.1-1 \mathrm{wt} . \%$ as shown in Figure $5 \mathrm{c}$ as the ST of base fluid is similar to that of Tyfocor ${ }^{\circledR}$ LS whatever the Gum Arabic content.

The effect of the addition of Triton X-100 to Tyfocor ${ }^{\circledR}$ LS is illustrated in Figure 5a, it induces a reduction of ST for the corresponding base fluids. With the lowest surfactant content, $0.1 \mathrm{wt} . \%, \mathrm{ST}$ is reduced by $10.8 \%$ at $283.15 \mathrm{~K}$ and $0.4 \%$ at $323.15 \mathrm{~K}$. For the higher Triton X-100 concentrations, the reduction rates become 13.9 and $5.5 \%$ on average at 283.15 and $323.15 \mathrm{~K}$, respectively. This evidences the effect of temperature on ST of this base fluid, below and above the CMC. Pluronic ${ }^{\circledR}$ P-123 addition to the Tyfocor ${ }^{\circledR}$ LS decreases the ST by 14.8 to $11.4 \%$ with increasing temperature from 283.15 to 323.15 $\mathrm{K}$, without any significant rate difference between the concentrations. The CMC is here achieved regardless of the surfactant content and can explain this result.

Figure 5 shows a decrease in ST for both base fluids and nanofluids with rising temperature, as expected [23,42], for the three surfactants Triton X-100, Pluronic ${ }^{\circledR}$ P-123 and Gum Arabic, respectively. The reduction rate of ST for Tyfocor ${ }^{\circledR} \mathrm{LS}$ alone in the tested temperature range is equal to $12.6 \%$.

For the samples prepared with Gum Arabic, ST of base fluids decreases following the same trend as that of Tyfocor ${ }^{\circledR}$ LS (Figure 5c) whatever the Gum Arabic content. In the case of the samples containing Pluronic ${ }^{\circledR}$ P-123, the ST reduction rate was lowered by the presence of surfactant, at a rate of $9.4 \%$ between 283.15 and $323.15 \mathrm{~K}$. However, no significant change was noticed with the surfactant content, as this content is always higher than CMC. In case of Triton X-100 samples (Figure 5a), ST decreases with temperature with a different trend from that observed for Tyfocor ${ }^{\circledR}$ LS. The reduction rate of ST with temperature also depends on surfactant content. This rate was equal to $2.0 \%$ in the case of the two base fluids with the lowest surfactant concentrations. For the base fluids with the two highest concentrations of surfactant (above the CMC), the decreasing rate is around $4.8 \%$.

As shown in Figure $5 a-c$, the effect of addition of FLG nanoparticles on nanofluids' ST depends on the nature and concentration of the surfactant used. FLG addition on ST for the samples prepared with Pluronic ${ }^{\circledR}$ P-123 (Figure 5b) has no significant effect on the ST measured values in the whole FLG concentration range from 0.05 to $0.5 \mathrm{wt} . \%$. ST behavior is here rather governed by the presence of Pluronic ${ }^{\circledR}$ P-123 than by the presence of FLG. Actually, in that case, while surfactant molecules adsorb to the FLG, the content of surfactant, higher than CMC is too high for the change in equilibrium and the modification of ST by the presence of the FLG nanoparticles in the medium. The findings are different when Gum Arabic is used as surfactant (Figure 5c) since the ST values increase after adding the FLGs. It seems here that adsorption of the Gum Arabic (GA) to graphene promotes the attraction between the graphene and base fluid molecules that reduces the intermolecular spacing, leading to the increase in the surface tension. The observed ST evolution is independent on the temperature and FLG concentration, an increase around $21.5 \%$ in ST is here reported whatever the FLG content.

For the nanofluids prepared with Triton X-100 (Figure 5a), the ST evolution is more complex. An increase in ST of $4.9 \%$ (with respect to the corresponding base fluid) was observed for the lowest mass loading of FLG, $0.05 \mathrm{wt} . \%$, at 283.15 and $293.15 \mathrm{~K}$. In absolute value, ST of this nanofluid is still lower than that of Tyfocor ${ }^{\mathbb{R}}$ LS alone, which can be explained by the reduced amount of surfactant molecules adsorbed at the liquid-gas interface competing with Triton X-100 adsorption onto soli-liquid interface, 
e.g., the FLG surface. By increasing FLG concentration within the nanofluids, a decrease in ST is observed and the ST reaches the values of the corresponding base fluids. The ST behavior is governed by the presence of surfactant and not only by that of the nanoparticle concentration in this domain, as the CMC is reached. For these nanofluids, a decrease in ST is obtained when the temperature is increased, except, surprisingly for the two lowest FLG concentrations. Such an unexpected trend is difficult to explain based on our current knowledge. Finally, when a decrease in ST of nanofluids is observed with the presence of nanoparticles and the increase of temperature, this could lead to an increase in heat flux in real systems $[23,46]$ which is of practical interest in energy applications.

\section{Conclusions}

Few-layer graphene (FLG) produced following a mechanical exfoliation method was used to develop nanofluids considering a commercial heat transfer fluid based on a mixture of water and propylene glycol and different nonionic surfactants. These nanofluids were experimentally characterized in terms of density and surface tension in a wide temperature range varying the mass content in FLG from 0.05 to $0.5 \%$. Overall, it is observed that the density of the prepared nanofluids decreases with temperature and slightly increases with FLG content in comparison to base fluids. The density evolution of the FLG-based nanofluids with temperature and FLG concentration is well predicted by the weight-average equation for density considering the densities of all components. From the experimental density results, the effects of temperature, nature and concentration of the surfactant, as well as FLG mass concentration on the isobaric thermal expansivity were also evaluated. It was shown that the isobaric thermal expansivity, which increases with temperature, was similar for all base fluids without any distinct effect of the used surfactant. In contrast to the base fluids, a decrease in this property was noticed in the presence of FLG with all the used base fluids. The surface tension of the different nanofluids was more sensitive to the type of surfactant and its content in relation with their CMC. Consequently, this property could evolve differently following the surfactant used and the FLG content. The surface tension of base fluids could decrease or remain unchanged following the surfactant, and the addition of FLG can induce an increase or may not strongly modify the surface tension. To complete the characterization of these nanofluids, the next step concerns the evaluation of their flow properties.

Author Contributions: “Conceptualization, B.V. and P.E.; FLG preparation, D.B.; Nanofluid preparation and FLG characterization, B.V., A.D. and D.B.; Investigation: S.H., D.C. and P.E.; data curation, S.H., D.C. and P.E.; writing — original draft preparation, S.H., D.C. and P.E.; writing—review and editing, S.H., D.C., P.E., B.V. and L.L.; supervision, B.V., L.L., T.M. and P.E.; project administration, P.E.; All authors have read and agreed to the published version of the manuscript".

Funding: P.E. acknowledges the European Union through the European Regional Development Fund (ERDF), the Ministry of Higher Education and Research, the French region of Brittany and Rennes Métropole for the financial support of surface tension experimental device. S.H. acknowledges EU COST for the STMS grant ref. COST-STSM-CA15119- 45590. D.C. is recipient of a postdoctoral fellowship from Xunta de Galicia (Spain). This investigation is a contribution to the COST (European Cooperation in Science and Technology) Action CA15119: Overcoming Barriers to Nanofluids Market Uptake (NanoUptake). This work was also partially supported by the Ministerio de Economía y Competitividad (Spain) and FEDER program through ENE2017-86425-C2-1-R project.

Acknowledgments: B.V. would like to thank Dr. Jaafar Ghanbaja and the microscopy platform (CC3M) at the Institut Jean Lamour for TEM and SEM observations.

Conflicts of Interest: The authors declare no conflict of interest.

\section{Nomenclature}

CNTs carbon nanotubes

ST surface tension $\left(\mathrm{mN} \cdot \mathrm{m}^{-1}\right)$

GO graphene oxide

rGO reduced graphene oxide 


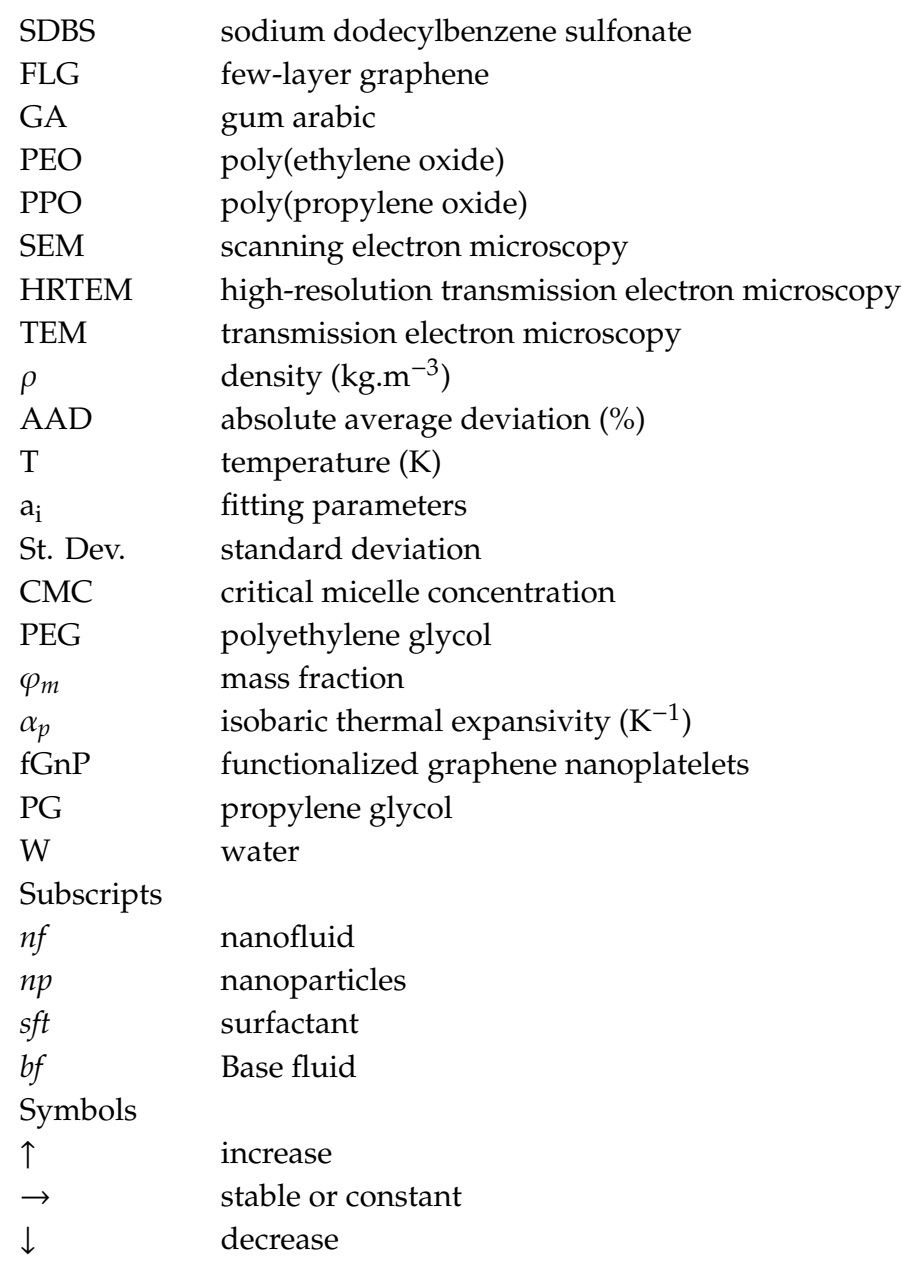

\section{References}

1. Choi, S.U.S.; Eastman, J.A. Enhancing Thermal Conductivity of Fluids with Nanoparticles, International Mechanical Engineering Congress and Exhibition; Argonne National Lab: Argonne, IL, USA, 1995; pp. 99-105.

2. Żyła, G.; Fal, J.; Estellé, P. Thermophysical and dielectric profiles of ethylene glycol based titanium nitride (TiN-EG) nanofluids with various size of particles. Int. J. Heat Mass Transf. 2017, 113, 1189-1199. [CrossRef]

3. Godson, L.; Raja, B.; Mohan Lal, D.; Wongwises, S. Enhancement of heat transfer using nanofluids-An overview. Renew. Sustain. Energy Rev. 2010, 14, 629-641. [CrossRef]

4. Wen, D.; Lin, G.; Vafaei, S.; Zhang, K. Review of nanofluids for heat transfer applications. Particuology 2009, 7,141-150. [CrossRef]

5. Cabaleiro, D.; Estellé, P.; Navas, H.; Desforges, A.; Vigolo, B. Dynamic Viscosity and Surface Tension of Stable Graphene Oxide and Reduced Graphene Oxide Aqueous Nanofluids. J. Nanofluids 2018, 7, 1081-1088. [CrossRef]

6. Kakaç, S.; Pramuanjaroenkij, A. Review of convective heat transfer enhancement with nanofluids. Int. J. Heat Mass Transf. 2009, 52, 3187-3196. [CrossRef]

7. Ramesh, G.; Prabhu, N.K. Review of thermo-physical properties, wetting and heat transfer characteristics of nanofluids and their applicability in industrial quench heat treatment. Nanoscale Res. Lett. 2011, 6, 334. [CrossRef]

8. Kleinstreuer, C.; Feng, Y. Experimental and theoretical studies of nanofluid thermal conductivity enhancement: A review. Nanoscale Res. Lett. 2011, 6, 229. [CrossRef]

9. Eggers, J.R.; Kabelac, S. Nanofluids revisited. Appl. Therm. Eng. 2016, 106, 1114-1126. [CrossRef]

10. Azmi, W.H.; Sharma, K.V.; Mamat, R.; Najafi, G.; Mohamad, M.S. The enhancement of effective thermal conductivity and effective dynamic viscosity of nanofluids-A review. Renew. Sustain. Energy Rev. 2016, 53, 1046-1058. [CrossRef] 
11. Timofeeva, E.V.; Yu, W.; France, D.M.; Singh, D.; Routbort, J.L. Nanofluids for heat transfer: An engineering approach. Nanoscale Res. Lett. 2011, 6, 182. [CrossRef]

12. Sarkar, J.; Ghosh, P.; Adil, A. A review on hybrid nanofluids: Recent research, development and applications. Renew. Sustain. Energy Rev. 2015, 43, 164-177. [CrossRef]

13. Minea, A.A. Challenges in hybrid nanofluids behavior in turbulent flow: Recent research and numerical comparison. Renew. Sustain. Energy Rev. 2017, 71, 426-434. [CrossRef]

14. Sundar, L.S.; Sharma, K.V.; Singh, M.K.; Sousa, A.C.M. Hybrid nanofluids preparation, thermal properties, heat transfer and friction factor-A review. Renew. Sustain. Energy Rev. 2017, 68, 185-198. [CrossRef]

15. Balandin, A.A. Thermal properties of graphene and nanostructured carbon materials. Nat. Mater. 2011, 10, 569-581. [CrossRef]

16. Cabaleiro, D.; Colla, L.; Barison, S.; Lugo, L.; Fedele, L.; Bobbo, S. Heat Transfer Capability of (Ethylene Glycol + Water)-Based Nanofluids Containing Graphene Nanoplatelets: Design and Thermophysical Profile. Nanoscale Res. Lett. 2017, 12, 53. [CrossRef]

17. Rasheed, A.K.; Khalid, M.; Rashmi, W.; Gupta, T.C.S.M.; Chan, A. Graphene based nanofluids and nanolubricants—Review of recent developments. Renew. Sustain. Energy Rev. 2016, 63, 346-362. [CrossRef]

18. Sadeghinezhad, E.; Mehrali, M.; Saidur, R.; Mehrali, M.; Tahan Latibari, S.; Akhiani, A.R.; Metselaar, H.S.C. A comprehensive review on graphene nanofluids: Recent research, development and applications. Energy Convers. Manag. 2016, 111, 466-487. [CrossRef]

19. Arshad, A.; Jabbal, M.; Yan, Y.; Reay, D. A review on graphene based nanofluids: Preparation, characterization and applications. J. Mol. Liq. 2019, 279, 444-484. [CrossRef]

20. Wanic, M.; Cabaleiro, D.; Hamze, S.; Fal, J.; Estellé, P.; Żyła, G. Surface tension of ethylene glycol-based nanofluids containing various types of nitrides: An experimental study. J. Therm. Anal. Calorim. 2020, 139, 799-806. [CrossRef]

21. Moffat, J.R.; Sefiane, K.; Shanahan, M.E.R. Effect of TiO2 Nanoparticles on Contact Line Stick-Slip Behavior of Volatile Drops. J. Phys. Chem. B 2009, 113, 8860-8866. [CrossRef]

22. Askounis, A.; Sefiane, K.; Koutsos, V.; Shanahan, M.E.R. Effect of particle geometry on triple line motion of nano-fluid drops and deposit nano-structuring. Adv. Colloid Interface Sci. 2015, 222, 44-57. [CrossRef] [PubMed]

23. Estellé, P.; Cabaleiro, D.; Żyła, G.; Lugo, L.; Murshed, S.M.S. Current trends in surface tension and wetting behavior of nanofluids. Renew. Sustain. Energy Rev. 2018, 94, 931-944. [CrossRef]

24. Incropera, F.P.; DeWitt, D.P.; Bergman, T.L.; Lavine, A.S. Introduction to Heat Transfer, 6th ed.; John Wiley: New York, NY, USA, 2007.

25. Kim, E.J.; Desforges, A.; Speyer, L.; Ghanbaja, J.; Gleize, J.; Estellé, P.; Vigolo, B. Graphene for Water-Based Nanofluid Preparation: Effect of Chemical Modifications on Dispersion and Stability. J. Nanofluids 2017, 6, 603-613. [CrossRef]

26. Cong, H.-P.; Chen, J.-F.; Yu, S.-H. Graphene-based macroscopic assemblies and architectures: An emerging material system. Chem. Soc. Rev. 2014, 43, 7295-7325. [CrossRef]

27. Ahammed, N.; Asirvatham, L.G.; Wongwises, S. Effect of volume concentration and temperature on viscosity and surface tension of graphene-water nanofluid for heat transfer applications. J. Therm. Anal. Calorim. 2016, 123, 1399-1409. [CrossRef]

28. Ilyas, S.U.; Ridha, S.; Abdul Kareem, F.A. Dispersion stability and surface tension of SDS-Stabilized saline nanofluids with graphene nanoplatelets. Colloids Surf. Physicochem. Eng. Asp. 2020, 592, 124584. [CrossRef]

29. Kamatchi, R.; Venkatachalapathy, S.; Abhinaya Srinivas, B. Synthesis, stability, transport properties, and surface wettability of reduced graphene oxide/water nanofluids. Int. J. Therm. Sci. 2015, 97, 17-25. [CrossRef]

30. Liu, Y.; Chen, B.; Wang, D.; Jiang, N.; Tan, J.; Fu, J.; Wu, B.; Hu, Y.; Guo, Z. Surface tension of supercooled graphene oxide nanofluids measured with acoustic levitation. J. Therm. Anal. Calorim. 2020. [CrossRef]

31. Zheng, Z.Z. Experimental Investigation on Surface Tension of Water-Based Graphene Oxide Nanofluids. Adv. Mater. Res. 2014, 1082, 297-301. [CrossRef]

32. Alawi, O.A.; Mallah, A.R.; Kazi, S.N.; Sidik, N.A.C.; Najafi, G. Thermophysical properties and stability of carbon nanostructures and metallic oxides nanofluids: Experimental approach. J. Therm. Anal. Calorim. 2019, 135, 1545-1562. [CrossRef]

33. Amiri, A.; Shanbedi, M.; Dashti, H. Thermophysical and rheological properties of water-based graphene quantum dots nanofluids. J. Taiwan Inst. Chem. Eng. 2017, 76, 132-140. [CrossRef] 
34. Azizi, M.; Honarvar, B. Investigation of thermophysical properties of nanofluids containing poly(vinyl alcohol)-functionalized graphene. J. Therm. Anal. Calorim. 2018, 133, 1259-1269. [CrossRef]

35. Ijam, A.; Saidur, R.; Ganesan, P.; Moradi Golsheikh, A. Stability, thermo-physical properties, and electrical conductivity of graphene oxide-deionized water/ethylene glycol based nanofluid. Int. J. Heat Mass Transf. 2015, 87, 92-103. [CrossRef]

36. Karami, H.; Papari-Zare, S.; Shanbedi, M.; Eshghi, H.; Dashtbozorg, A.; Akbari, A.; Mohammadian, E.; Heidari, M.; Sahin, A.Z.; Teng, C.B. The thermophysical properties and the stability of nanofluids containing carboxyl-functionalized graphene nano-platelets and multi-walled carbon nanotubes. Int. Commun. Heat Mass Transf. 2019, 108, 104302. [CrossRef]

37. Sani, E.; Vallejo, J.P.; Cabaleiro, D.; Lugo, L. Functionalized graphene nanoplatelet-nanofluids for solar thermal collectors. Sol. Energy Mater. Sol. Cells 2018, 185, 205-209. [CrossRef]

38. Vallejo, J.P.; Pérez-Tavernier, J.; Cabaleiro, D.; Fernández-Seara, J.; Lugo, L. Potential heat transfer enhancement of functionalized graphene nanoplatelet dispersions in a propylene glycol-water mixture. Thermophysical profile. J. Chem. Thermodyn. 2018, 123, 174-184. [CrossRef]

39. Vallejo, J.P.; Álvarez-Regueiro, E.; Cabaleiro, D.; Fernández-Seara, J.; Fernández, J.; Lugo, L. Functionalized graphene nanoplatelet nanofluids based on a commercial industrial antifreeze for the thermal performance enhancement of wind turbines. Appl. Therm. Eng. 2019, 152, 113-125. [CrossRef]

40. Yarmand, H.; Gharehkhani, S.; Shirazi, S.F.S.; Amiri, A.; Alehashem, M.S.; Dahari, M.; Kazi, S.N. Experimental investigation of thermo-physical properties, convective heat transfer and pressure drop of functionalized graphene nanoplatelets aqueous nanofluid in a square heated pipe. Energy Convers. Manag. 2016, 114, 38-49. [CrossRef]

41. Yarmand, H.; Gharehkhani, S.; Shirazi, S.F.S.; Amiri, A.; Montazer, E.; Arzani, H.K.; Sadri, R.; Dahari, M.; Kazi, S.N. Nanofluid based on activated hybrid of biomass carbon/graphene oxide: Synthesis, thermo-physical and electrical properties. Int. Commun. Heat Mass Transf. 2016, 72, 10-15. [CrossRef]

42. Berrada, N.; Hamze, S.; Desforges, A.; Ghanbaja, J.; Gleize, J.; Maré, T.; Vigolo, B.; Estellé, P. Surface tension of functionalized MWCNT-based nanofluids in water and commercial propylene-glycol mixture. J. Mol. Liq. 2019, 293, 111473. [CrossRef]

43. Oyinlola, M.A.; Shire, G.S.F.; Moss, R.W. Thermal analysis of a solar collector absorber plate with microchannels. Exp. Therm. Fluid Sci. 2015, 67, 102-109. [CrossRef]

44. Hamze, S.; Berrada, N.; Cabaleiro, D.; Desforges, A.; Ghanbaja, J.; Gleize, J.; Bégin, D.; Michaux, F.; Maré, T.; Vigolo, B.; et al. Few-layer graphene-based nanofluids with enhanced thermal conductivity. Nanomaterials 2020, 10, 1258. [CrossRef] [PubMed]

45. Vargaftik, N.B.; Volkov, B.N.; Voljak, L.D. International Tables of the Surface Tension of Water. J. Phys. Chem. Ref. Data 1983, 12, 817-820. [CrossRef]

46. Gómez-Villarejo, R.; Aguilar, T.; Hamze, S.; Estellé, P.; Navas, J. Experimental analysis of water-based nanofluids using boron nitride nanotubes with improved thermal properties. J. Mol. Liq. 2019, 277, 93-103. [CrossRef]

47. Bianco, A.; Cheng, H.-M.; Enoki, T.; Gogotsi, Y.; Hurt, R.H.; Koratkar, N.; Kyotani, T.; Monthioux, M.; Park, C.R.; Tascon, J.M.D.; et al. All in the graphene family-A recommended nomenclature for two-dimensional carbon materials. Carbon 2013, 65, 1-6. [CrossRef]

48. Available online: https://tyfo.de/en/produkt/tyfocor-ls (accessed on 9 June 2020).

49. Cabaleiro, D.; Pastoriza-Gallego, M.J.; Piñeiro, M.M.; Legido, J.L.; Lugo, L. Thermophysical properties of (diphenyl ether+biphenyl) mixtures for their use as heat transfer fluids. J. Chem. Thermodyn. 2012, 50, 80-88. [CrossRef]

50. Available online: https://chemistry.stackexchange.com/questions/45079/does-adding-mass-to-a-liquid-notwater-increase-the-volume (accessed on 9 June 2020).

51. Available online: https://www.carolina.com/teacher-resources/interactive/chemistry-lost-volumedemonstration/tr10785.tr (accessed on 9 June 2020).

52. Pastoriza-Gallego, M.J.; Casanova, C.; Legido, J.L.; Piñeiro, M.M. CuO in water nanofluid: Influence of particle size and polydispersity on volumetric behaviour and viscosity. Fluid Phase Equilibria 2011, 300, 188-196. [CrossRef] 
53. Pastoriza-Gallego, M.J.; Casanova, C.; Páramo, R.; Barbés, B.; Legido, J.L.; Piñeiro, M.M. A study on stability and thermophysical properties (density and viscosity) of $\mathrm{Al} 2 \mathrm{O} 3$ in water nanofluid. J. Appl. Phys. 2009, 106, 064301. [CrossRef]

54. Cabaleiro, D.; Pastoriza-Gallego, M.J.; Piñeiro, M.M.; Lugo, L. Characterization and measurements of thermal conductivity, density and rheological properties of zinc oxide nanoparticles dispersed in (ethane-1,2-diol+water) mixture. J. Chem. Thermodyn. 2013, 58, 405-415. [CrossRef]

55. Zafarani-Moattar, M.T.; Majdan-Cegincara, R. Stability, rheological, magnetorheological and volumetric characterizations of polymer based magnetic nanofluids. Colloid Polym. Sci. 2013, 291, 1977-1987. [CrossRef]

56. Marcos, M.A.; Cabaleiro, D.; Hamze, S.; Fedele, L.; Bobbo, S.; Estellé, P.; Lugo, L. NePCM Based on Silver Dispersions in Poly(Ethylene Glycol) as a Stable Solution for Thermal Storage. Nanomaterials 2019, 10, 19. [CrossRef] [PubMed]

57. Available online: http://candmz04.brenntag.ca/MSDS/Fr/00070113.pdf (accessed on 9 June 2020).

58. Available online: http://www.merckmillipore.com/FR/fr/product/Gum-arabic,MDA_CHEM-104228 (accessed on 9 June 2020).

59. Cabaleiro, D.; Segovia, J.J.; Martín, M.C.; Lugo, L. Isobaric heat capacity at high pressure, density, and viscosity of (diphenyl ether + biphenyl) mixtures. J. Chem. Thermodyn. 2016, 93, 86-94. [CrossRef]

60. Cabaleiro, D.; Pastoriza-Gallego, M.J.; Gracia-Fernández, C.; Piñeiro, M.M.; Lugo, L. Rheological and volumetric properties of TiO2-ethylene glycol nanofluids. Nanoscale Res. Lett. 2013, 8, 286. [CrossRef] [PubMed]

61. Korolovych, V.F.; Bulavin, L.A.; Prylutskyy, Y.I.; Khrapatiy, S.V.; Tsierkezos, N.G.; Ritter, U. Influence of Single-Walled Carbon Nanotubes on Thermal Expansion of Water. Int. J. Thermophys. 2014, 35, 19-31. [CrossRef]

62. Nayak, A.K.; Singh, R.K.; Kulkarni, P.P. Measurement of volumetric thermal expansion coefficient of various nanofluids. Tech. Phys. Lett. 2010, 36, 696-698. [CrossRef]

63. Nayak, A.K.; Singh, R.K.; Kulkarni, P.P. Thermal expansion characteristics of Al2O3 nanofluids: More to understand than understood. Appl. Phys. Lett. 2009, 94, 094102. [CrossRef]

64. Radulovic, J.; Sefiane, K.; Shanahan, M.E.R. On the effect of pH on spreading of surfactant solutions on hydrophobic surfaces. J. Colloid Interface Sci. 2009, 332, 497-504. [CrossRef] 